\title{
WIZUALNE SŁOWNIKI EMOCJI \\ PODCZAS PANDEMII COVID-19 W MEDIALNYCH PRZEKAZACH ARTYSTYCZNYCH
}

\section{MEDIATYZACJA KULTURY I SZTUKI W OKRESIE PANDEMII COVID-19}

Mediatyzacja sfery publicznej, w tym także kultury, nie jest zjawiskiem nowym, a raczej wynikiem zmian społecznych, jakie zachodzą we współczesnych, technologicznie nasyconych, a więc coraz bardziej rozwiniętych społeczeństwach. Mediatyzacja oznacza ,pewien zespół procesów wynikających ze zmian zarówno w samych mediach, jak i zmian społecznych oraz kulturowych" i jako taki podlega naukowym rozważaniom ${ }^{1}$. W sytuacji kryzysowej proces ten gwałtownie przyśpieszył, i to w skali globalnej, bazując na kreatywności ludzi zatrudnionych w kulturze. Na przykład stworzona w 2011 r. platforma Google Arts \& Culture rozrosła się w 2020 r. do ponad 2000 instytucji kulturalnych z ponad 80 krajów. Według analizy Google Trends popularność platformy wzrosła wyjątkowo w marcu 2020 r., a wyszukiwania online hasła „Google Arts \& Culture” zwiększyły się czterokrotnie $^{2}$. Epidemia SARS-CoV-2 zmieniła podejście do rzeczywistości na całym świecie. W obawie o swoje zdrowie i życie ludzie zawiesili normalną

Dr MaŁgorzata SŁaweK-Czochra - Katolicki Uniwersytet Lubelski Jana Pawła II, Wydział Nauk Społecznych, Instytut Dziennikarstwa i Zarządzania, Katedra Komunikacji Wizualnej i Nowych Mediów (adiunkt); adres do korespondencji-e-mail: malgorzataczochra@kul. lublin.pl; ORCID: https://orcid.org/0000-0002-4732-1341.

${ }^{1}$ Friedrich KROTZ: Die Mediatisierung kommunikativen Handels. Der Wandel von Alltag und sozialen Beziehungen, Kultur und Gesellschaft durch die Medien (Wiesbaden: Westdeutscher Verlag, 2007).

${ }^{2}$ Google. Arts and Culture, dostęp 06.11.2020, https://artsandculture.google.com/; Ocula Magazine, dostęp 06.11.2020, https://ocula.com/magazine/art-news/interest-in-google-arts-culture-sky rockets-as/. 
aktywność. Puste ulice i budynki użyteczności publicznej to widok, który w świecie przed pandemią był nie do pomyślenia i pasowałby konwencją do horroru lub dramatu. Aby ograniczyć rozprzestrzenianie się koronawirusa, rządy państw na całym świecie zaczęły wprowadzać ograniczenia, obostrzenia i restrykcje, zamykając ludzi w domach w „dobrowolnej” lub ustawowej izolacji.

W poczuciu odpowiedzialności i w obawie o miejsca pracy kultura, a konkretnie artyści przenieśli się do sieci, próbując pozostać w kontakcie ze swoimi stałymi odbiorcami, zapewnić im rozrywkę, promować markę i gwarantować pracownikom ciągłość działań. Internetowe transmisje spektakli teatralnych, wirtualne wycieczki po muzeach oraz udostępnianie części zbiorów bibliotecznych w wydaniach internetowych - to tylko niektóre z działań podjętych przez placówki kulturalne.

Relokacja kultury w przestrzeń wirtualną doprowadziła do zmian na wielu poziomach. Po pierwsze, w sposobie realizacji, ponieważ kluczowym elementem działalności kulturalnej są nie tylko premiery czy wernisaże, ale często niewidoczny, długotrwały i wymagający proces badań, prób, projektowania itd. Po drugie, wirtualny świat kultury jest obecnie udostępniany w Internecie za darmo, tak jakby nie wiązały się z tym żadne koszty w świecie realnym. Kolejne zmiany dotyczą dostępności zasobów i przeżycia artystycznego po stronie odbiorcy. Z jednej strony świat sztuki jest dostępny na niespotykaną dotąd skalę (odbiorcy mogą uczestniczyć w najlepszych festiwalach filmowych online, oglądać opery w Metropolitan Opera i przedstawienia w Berliner Ensemble, zwiedzać Galerię Uffizi online), z drugiej zaś strony zostaje zaburzona percepcja dzieła, doświadczenie przestrzeni galerii, materialności obrazów - ich faktur i rozmiarów, a wreszcie przeżywanie tego z innymi ludźmi. Wiele dziedzin sztuki opiera się właśnie na takim bezpośrednim, relacyjnym doświadczeniu. Pojawiły się więc nowe, zapośredniczone technicznie więzi między odbiorcami sztuki, którzy - pochodząc z różnych kultur i zakątków świata - wymieniają się spostrzeżeniami i emocjami już nie w kuluarach miejskiego teatru, ale w przestrzeni wirtualnej.

\section{EMOCJE W SZTUCE}

W literaturze naukowej i w języku potocznym używa się zamiennie określeń „emocje” i „uczucia”. Pojęcia te nie są sprzeczne, ale mogą oznaczać dwa przeciwległe bieguny procesu, który prowadzi od prostych emocji 
poprzez emocje złożone aż do najbardziej złożonych uczuć, takich jak przyjaźń czy miłość. Emocję określa się jako „proces związany z czynnością ośrodków podkorowych, głównie podwzgórza i sąsiednich struktur międzymózgowia, przy uwzględnieniu koordynującej czynności kory mózgu. Uczucia zaś postrzegane są jako procesy związane z korą mózgową"3. W niniejszym opracowaniu w centrum zainteresowania znajdą się emocje.

Według Carrolla E. Izarda na system emocyjny składa się dziewięć głównych emocji: zainteresowanie, radość, zdziwienie, smutek, złość, wstyd, strach, wstręt i pogarda ${ }^{4}$. Dyskusja dotycząca liczby emocji wciąż się toczy, ponieważ emocje nie są stanami pojedynczymi, a raczej grupami pokrewnych stanów i przyjmują różne formy. Dotychczasowe badania psychologów wskazują na kulturową stałość wyrazu mimicznego pięciu emocji określonych przez Paula Ekmana jako podstawowe. Do emocji podstawowych zalicza on gniew, strach, smutek, radość i wstręt ${ }^{5}$.

Emocje modeli od dawna stanowią inspirację dla artystów, którzy starają się zatrzymać czy też oddać je w swoich dziełach. Poprzez sztukę możliwe jest także przekazywanie emocji samego artysty. Recepcja dzieła sztuki może też wpływać na emocje po stronie odbiorcy, poprawiać nastrój lub sprawiać, że zapragnie on zmieniać świat rzeczywisty. W literaturze przedmiotu funkcjonują zatem łącznie lub równolegle emocje nadawcy (artysty), te zawarte przez niego w dziele sztuki, i emocje odbiorcy ${ }^{6}$.

Bodziec estetyczny w odbiorze emocjonalnym może poruszać odbiorcę dwutorowo: poprzez elementy formalne dzieła sztuki lub/i poprzez przedstawioną treść. W związku $\mathrm{z}$ tym istotny wydaje się przede wszystkim sposób tworzenia dzieła.

Do elementów formalnych zaliczamy kolorystykę, światło, strukturę kompozycyjną, elementy stylistyczne, wartości estetyczne oraz sposób prezentowania postaci.

Jednym z najważniejszych środków jest kolor, który może być stosowany jako ogólna tonacja lub akcent barwny i w obu przypadkach mieć zasadniczy wpływ na emocjonalny odbiór dzieła. Choć teoria koloru rozwijała się już

\footnotetext{
${ }^{3}$ Janusz ReYKOwsKi, Eksperymentalna psychologia emocji (Warszawa: Książka i Wiedza 1974), 14

${ }^{4}$ Carroll E. IzARD, The face of emotion (New York: Appleton-Century-Crofts, 1971), 207.

${ }^{5}$ Ibid.; Paul Ekman, „Wszystkie emocje są podstawowe”, w: Natura emocji, red. Paul Ekman i Richard J. Davidson (Gdańsk: GWP, 1998), 23; John B. WATSON, Behaviorism (New York: Norton, 1924), 10.

${ }^{6}$ Aleksandra JASIELSKA, „Reprezentacja współczesnych modeli emocji w dziełach sztuki”, „Teksty Drugie”, z. 6 (2013): 207.
} 
w myśli filozoficznej $\mathrm{V}$ wieku przed Chr., to nigdy wcześniej rola koloru i barwy nie budziła takiego zainteresowania, jak ma to miejsce współcześnie ${ }^{7}$. Znajdują się one w kręgu rozważań nie tylko artystów i historyków sztuki, ale również wielu innych dyscyplin naukowych, takich jak psychologia, antropologia kultury, socjologia czy lingwistyka. Należy zauważyć, że niektóre $\mathrm{z}$ nich są niejako wbudowane w świat życia człowieka przez naturę, np. ostre, ostrzegawcze ubarwienie trujących osobników, tj. czerwień czy żółć i czerń to dziś także element znaków ostrzegawczych. John Gage zwraca uwagę, że „wyodrębnianie koloru ujawnione w języku musi pozostawać w relacji do szerszego doświadczenia koloru w danej kulturze, a to doświadczenie jest $\mathrm{w}$ obrębie tej kultury różne dla różnych grup, dla których kolor posiada jakieś znaczenie" ${ }^{\prime}$. Niezależnie od tego, czy przyjmiemy perspektywę artystycznego znaczenia koloru w sztuce, czy perspektywę psychologiczną, znaczenie i odbiór kolorów ma zazwyczaj podłoże kulturowe, choć może być też indywidualne. Maria Rzepińska pisze, że malarz nie musi wiedzieć, dlaczego używa kolorów, ale wie, jak używać środków malarskich do obrazowania ${ }^{9}$. Nie oznacza to, że artyści nie interesują się sposobem oddziaływania barw i kolorów. Na przykład Wassily Kadinsky, dążąc do odkrycia źródeł ogólnego prawa, które dotyczyło w znacznym stopniu reakcji na kolory, sięgnął po kwestionariusz pytań należący do psychologii eksperymentalnej $^{10}$.

Zasadniczo do oddawania emocji pozytywnych, takich jak radość czy szczęście, używa się kolorów żywych, które mogą mieć odcień ciepły lub zimny, np. żółć, będąca kolorem energetycznym, wręcz obsesyjnym, wyraża pozytywizm, zabawę, optymizm. Ilustruje także kreatywność i sprzyja jej rozwojowi ${ }^{11}$. Złość oddaje zazwyczaj kolor czerwony, który wyraża agresję, niebezpieczeństwo i prowokuje. Aby w pełni świadomie korzystać z mocy niespokojnej czerwieni, należy wyłączyć lewą półkulę mózgu, nie eksplorować rozumowo, nie analizować obrazu, lecz poczuć go ${ }^{12}$. Czerwień oznacza

\footnotetext{
${ }^{7}$ H. B. GotTschalk, „The 'Decoloribus' and Its Author”, Hermes 92 (1964): 85.

${ }^{8}$ John Gage, Kolor $i$ kultura. Teoria $i$ znaczenie koloru od antyku do abstrakcji, thum. Joanna Holzman (Kraków: Universitas, 2008), 79.

${ }^{9}$ Maria RZEPIŃSKA, Historia koloru $w$ dziejach malarstwa europejskiego (Kraków: Wydawnictwo Literackie, 1983), 39-40.

${ }^{10}$ GAGE. Kolor i kultura, 261.

${ }^{11}$ Eva Heller i Joaqimo Chamorro Mielke, Psicología del color: cómo actúan los colores sobre los sentimientos y la razón (Barcelona: Gustavo Gili, 2017) (w opracowaniu brak numeracji stron).

${ }^{12}$ Patti Bellantoni, Jeśli to fiolet, to ktoś umrze: teoria koloru w filmie, thum. Monika Dańczyszyn (Warszawa: Wydawnictwo Wojciech Marzec, 2010), 28.
} 
wojnę, przemoc i nienawiść ${ }^{13}$. Smutek i strach to matowe, zimne barwy, najczęściej czernie, szarości, biel, niekiedy także barwy złamane. Przykładem barwy zimnej może być fiolet (kolor pozacielesny), który nawiązuje do przejścia, odejścia, śmierci, rytuału, magii, duchowości. Jest mistyczny i paranormalny ${ }^{14}$. Smutek jednak częściej oddawany jest w kolorze błękitnym jako wyraz melancholii, zadumy, refleksji i niemocy oraz opuszczenia ${ }^{15}$. Niebieski to kolor harmonii i współczucia ${ }^{16}$. Strach jest często przedstawiany $\mathrm{w}$ zieleni, która jest kolorem trucizny, choroby, ale i nadziei (uniknięcie niebezpieczeństwa, koniec problemów) ${ }^{17}$. Duże znaczenie ma też nasycenie koloru. Inaczej odbiera się barwy czyste, które są bardzo wyraziste, a inaczej złamane. Sąsiedztwo barw oraz kształty obiektów również wpływają na odbiór emocjonalny koloru.

Kolejnym stosowanym środkiem jest światło, którego może być dużo (w fotografii tzw. wysoki klucz) lub mało (niski), usytuowane w obrazie lub poza nim, rzeczywiste (naturalne) lub wykreowane (sztuczne). Już w XVII wieku światło kojarzono z dobrem, ciemność zaś ze złem ${ }^{18}$. Szczęście to zazwyczaj światło wysokie - jasność i rozmycie przy prawie całkowitym zaniku cieni. Delikatne kontury i przejścia między kolorami (sfumato). Radość bywa przedstawiana jako smugi świetlne omiatające postacie lub z nich promieniujące, natomiast złość, smutek i strach to ciemność. Złość i strach mogą być eksponowane za pomocą oświetlenia konturowego, mocnych kontrastów. Gdy światła jest mało, zazwyczaj w ciemnej tonacji obrazu pojawiają się głębokie cienie. Oddając smutek, artysta również korzysta z niewielkiej ilości światła, ale unika wyraźnych kontrastów, rozmywa tło, skupiając się na istotnych obiektach.

Na przedstawianie emocji ma wpływ także struktura kompozycyjna obrazu. Kompozycja może być na przykład otwarta lub zamknięta, statyczna lub dynamiczna, symetryczna lub asymetryczna, centralna, itd. Kompozycja zamknięta, statyczna, symetryczna potęgują wrażenie spokoju, podczas gdy kompozycje otwarte, dynamiczne, asymetryczne oddają ruch. Pierwszy

${ }^{13}$ Heller i Chamorro Mielke, Psicología del color.

${ }^{14}$ Bellantoni, Jeśli to fiolet, to ktoś umrze, 200-212.

${ }^{15}$ Ibid., 25, 93, 110.

${ }^{16}$ Heller i Chamorro Mielke, Psicología del color.

${ }^{17}$ Bellantoni, Jeśli to fiolet, to ktoś umrze; Heller i Chamorro Mielke, Psicología del color; Zbigniew NęCKI, Izabela Sowa i Jerzy RosińsKI, Psychologia reklamy, w: Ze świata reklamy, red. Andrzej S. Barczak i Andrzej Pitrus (Kraków: Wydawnictwo Uniwersytetu Jagiellońskiego, 1999), 26.

${ }^{18}$ Bożena BocıeK, „Naturalne i nadprzyrodzone znaczenie symboliki światła w malarstwie okresu baroku", Studia Elbląskie 12 (2011): 140. 
z układów podkreśla takie emocje, jak smutek i strach, drugi - radość i złość, gdyż są one zazwyczaj gwałtowne, pełne ruchu. Emocje mogą też być potęgowane przez wielkość elementów, np. strach to mały człowiek w otoczeniu ogromnych przedmiotów, jak drzewo, fale etc. ${ }^{19} \mathrm{~W}$ przypadku wizualizacji, niektórych emocji dla ich podkreślenia wprowadza się pewien bodziec w skład elementów kompozycji, np. złość czy szczęście łatwiej odczytać, gdy zna się ich przyczynę, smutek natomiast staje się czytelny w pustce, w kompozycji wyczyszczonej ze zbędnych elementów.

Niezwykle istotnym elementem emocjonalnego przekazu dzieła sztuki są elementy stylistyczne, ponieważ to dzięki nim odbiorca nadaje znaczenia, porządkuje i kondensuje emocje. Złość może być akcentowana przez rytmizację elementów i wszelkie ich powtórki. Smutek jest domeną przenośni, czyli nadawaniu nowego, szerszego znaczenia, często dramatycznego (metafora). Metafory wizualne opierają się na zestawieniu obrazów, które osobno znaczą co innego, a w połączeniu nabierają nowego znaczenia. Metafora nie ma charakteru dosłownego i często odwołuje się do wiedzy odbiorcy, jego przygotowania kulturowego. Strach może być wywoływany poprzez stopniowanie, które budzi niepokój, jak i poprzez zastosowanie elipsy, zmuszającej odbiorcę do poszukiwania brakujących na obrazie elementów. Do ukazania emocji pozytywnych, takich jak szczęście i radość, artysta może zastosować metaforę, powtórzenia elementów, potęgując nasycenie emocjonalne dzieła lub groteskę. Ta ostatnia może wywołać śmiech lub grozę, która jest formą strachu $^{20}$. Do elementów stylistycznych zaliczamy także symbole. Według Leszka Polonego pojęcie symbolu w myśli humanistycznej XIX i XX stulecia nie tylko rozszerza i zawęża swój zakres, zmienia swe znaczenie w kontekście poznawczym różnych dziedzin naukowych, ale też „ożywa i obumiera lub też przenosi swe znaczenie na pojęcie opozycyjne lub podrzędne"21. Jak twierdzi Polony, w obliczu owych przemian wszelaka próba projektowania na nowo definicji tych terminów wydaje się przedsięwzięciem poznawczo chybionym i beznadziejnym. W tej sytuacji lepiej zwrócić się ku znaczeniom pierwotnym, gdzie symbol to zmysłowy znak niewidzialnej

${ }^{19}$ Anna MAzelA. „Surrealistyczne wizje lęku w fotografiach Kaveha Hosseiniego”, w: Anatomia strachu. Strach, lęk i ich oblicza we wspótczesnej kulturze, red. Bogusława Bodzioch-Bryła i Lilianna Dorak-Wojakowska (Kraków: Wydawnictwo Naukowe Akademii Ignatianum w Krakowie, 2017), 355.

${ }^{20}$ Lee Byron Jennings, „Termin 'groteska'”, tłum. Maria Bożenna Fedewicz, w: Groteska. Tematy teoretyczno-literackie, red. Michał Głowiński (Gdańsk: słowo/obraz terytoria, 2003, 31-53).

${ }^{21}$ Leszek Polony, Symbol i muzyka (Kraków: Akademia Muzyczna, 2011), 11-99. 
treści, nie traktując ich jednak jako ostateczne ${ }^{22}$. Piotr Sztompka rozumie znak jako „wskaźnik pewnego stanu rzeczy oparty na prawidłowościach przyrodniczych, w myśl których występuje on razem $\mathrm{z}$ tym stanem lub go poprzedza" ${ }^{23}$. Symbol z kolei to „wskaźnik pewnego stanu rzeczy oparty na przyjętej w danej zbiorowości dowolnej konwencji. [...] Symbol to coś innego niż przedmiot, którego doświadczamy" ${ }^{24}$. Clifford Geertz w swojej definicji symbolu wyraźnie podkreśla funkcję symbolu jako „nośnika jakiejś koncepcji” ${ }^{25}$. W roli symbolu mogą wystąpić „wszelkie przedmioty, akty, zdarzenia, cechy lub relacje”. Symbole to ,[...] namacalne przedstawienia pojęć, abstrakcje wypreparowane $\mathrm{z}$ doświadczenia i utrwalone $\mathrm{w}$ dostrzegalnych, widocznych formach, konkretne ucieleśnienia idei, postaw, sądów, tęsknot czy wierzeń" ${ }^{26}$. W ich roli mogą występować także kolory. Użycie symboli może skierować odbiorcę ku właściwej emocji poprzez odniesienie do jego wiedzy z zakresu literatury, religii czy mitologii. Inna rzecz, że niektóre znaki i symbole, które nie są bezpośrednio wizualną egzemplifikacją konkretnej emocji, mogą te emocje wywoływać, np. sęp - śmierćc ${ }^{27}$, a więc pojawia się emocja strachu.

Wartości estetyczne dzieła, które są obierane często bezrefleksyjnie, nie stanowią jedynie części doświadczenia estetycznego, ale wykraczają poza nie. Mieczysław Wallis dzieli wartości estetyczne na łagodne i ostre. Do łagodnych zalicza piękno i śliczność, które wywołują jedynie przyjemne odczucia. Do drugiej kategorii zalicza natomiast tragizm, groteskowość, charakterystyczność, ekspresyjną brzydotę, ale także wzniosłość ${ }^{28}$. Szczęście może być tu wywołane przez piękno, np. krajobrazu. Strach, złość czy smutek pojawiają się $\mathrm{w}$ konfrontacji $\mathrm{z}$ brzydotą i rozkładem jako różne nasilenie emocji nakierowanej na przedmiot, sprawcę lub stan rzeczy.

Ostatnim z elementów formalnych jest sposób ukazania postaci. Samo umieszczenie i rozpoznanie przez odbiorcę konkretnej postaci na obrazie może nieść z sobą ładunek emocjonalny. Może to być postać realistyczna, fikcyjna lub nawet fantastyczna. Nie mniej ważna jest czynność postaci,

${ }^{22}$ Polony, Symbol i muzyka, 98-99.

${ }^{23}$ Piotr SzTOMPKA, Socjologia (Kraków: Znak, 2002), 288-307.

${ }^{24}$ Ibid.

${ }^{25}$ Clifford Geertz, Interpretacja kultur. Wybrane eseje, tłum. Maria Piechaczek (Kraków: Wydawnictwo Uniwersytetu Jagiellońskiego, 2005), 113.

${ }^{26}$ Ibid.

${ }^{27}$ Władysław Kopalı́́ski, Słownik symboli (Warszawa: Oficyna Wydawnicza RYTM, 2012), s.v.

${ }^{28}$ Mieczysław WALlis, „Wartości estetyczne łagodne i ostre”, w: Wybór pism estetycznych, red. Teresa Pękala (Kraków: Universitas, 2004), 197-213. 
której rozpoznanie i empatia po stronie odbiorcy umożliwia odbiór emocjonalny dzieła. Istnieją bowiem elementy wizualne, jak płacz, który jest przypisywany radości, smutkowi czy złości. Złość (gniew, agresja, wściekłość) widoczna jest przez układ mięśniowy twarzy, zaciśnięte pięści, rozszerzone źrenice, krzyk, a nawet płacz. Smutek (żal, bezradność) wyraźnie widać przez przywołany już płacz, ale także spuszczony wzrok, zamyślenie czy bezruch. Szczęście odczytujemy z uśmiechu, rozszerzonych źrenic, łez czy skrajnego zachowania - od dynamizmu do błogiego bezruchu. Strach często deformuje człowieka, postawa bohatera przekazu medialnego jest pochylona, skulona, wciśnięta w ciasne pomieszczenie, kąt. Strach uwidocznia się poprzez kontrasty: zaciśnięte lub szeroko otwarte oczy, krzyk lub zaniemówienie. Może też przybrać formę ataku lub ucieczki.

Emocje mogą też zostać utrwalone poprzez treść obrazu. Pierwszym ze sposobów jest nadanie dziełu tytułu, który jest językową podpowiedzią do dalszego obcowania z wizualizacją. Może odnosić się wprost do konkretnej emocji lub tylko ją sugerować poprzez związki kulturowe. Podobnie jest z tematem dzieła, choć teoretycznie tematyka najszybciej ustawia sytuację recepcji. Już samo opracowanie sposobu ujęcia tematu może być dla artysty nie tylko wyzwaniem, ale i tematem samym w sobie, np. sposób przedstawianie przestrzeni w dziele sztuki. Ostatnim ze sposobów wywoływania emocji w dziele sztuki poprzez treść jest motyw, czyli idea, wątek lub postać utrwalone w kulturze, powtarzające się w wytworach artystycznych różnych epok. Poszukując źródła motywów, często można dotrzeć do różnych religii i mitologii.

\section{METODOLOGIA}

Badania tworzenia i odbioru wytworu sztuki w kontekście emocji wykazują odwieczną dychotomię między sferą intelektualną poznawczą i sferą emocjonalną estetyczną (uczuciową) ${ }^{29}$. W związku z tym właściwą drogą wydaje się badanie emocji $\mathrm{w}$ zgodzie $\mathrm{z}$ postulatem transdyscyplinarności, paradygmatycznego eklektyzmu oraz synkretyzmu metodologicznego. $\mathrm{W}$ tym opracowaniu zostaną zastosowane dwie techniki badawcze: analiza zawartości oraz analiza dzieła artystycznego, oparta na założeniach zawartych w pismach

\footnotetext{
${ }^{29}$ Por. Bogusław SkowroneK, „Ciało, emocje, rozum. Raz jeszcze o mechanizmach odbioru filmu", Annales Universitatis Mariae Curie-Skłodowska. Sectio N, Educatio Nova, vol. 2 (2017): 163-174; Ed S. TAN, „Film fabularny jako maszyna emocji”, w: Kognitywna teoria filmu. Antologia przekładów, red. Jacek Ostaszewski (Kraków: Wydawnictwo Baran i Suszczyński, 1999), 248-276.
} 
Erwina Panofsky'ego ${ }^{30}$. Ich połączenie pozwoli na rzetelne opracowanie i interpretację materiałów medialnych, przy czym analiza dzieła artystycznego ma tu charakter uzupełniający, pozwalający na pogłębione odczytanie znaczeń wizualizacji zawartych na fotografiach, grafikach i obrazach prezentowanych w sieci.

Analiza zawartości ma ponad sześćdziesięcioletnią historię i cieszy się rosnącą popularnością. Jej przydatność w badaniach akademickich i komercyjnych została wielokrotnie udowodniona, a jej teoria opisana ${ }^{31}$. Na potrzeby tego opracowania przyjęto, że jest to technika badawcza służąca do wyciągania powtarzalnych i ważnych wniosków z tekstu w kontekście ich użycia ${ }^{32}$.

Materiał badawczy w niniejszym opracowaniu stanowią ilustracje pochodzące ze stron internetowych, uzyskane za pomocą wyszukiwarki Google, cieszącej się największą popularnością wśród użytkowników, za pomocą słów kluczowych ,art and coronavirus”. Ze względu na dużą liczbę wyświetlonych wyników zdecydowano, że badaniu zostanie poddanych 100 wizualizacji, które znalazły się na górze mozaiki obrazów w zakładce Grafika. Uzyskany w ten sposób materiał został oczyszczony z powtórzeń i fragmentów, wstępnie skategoryzowany i poddany kodowaniu otwartemu przy użyciu klucza kategoryzacyjnego, zaprojektowanego w celu zbadania emocji w przekazach wizualnych.

Analiza dzieła artystycznego według metody Panofsky'ego pozwala na konstruowanie znaczenia obrazu na trzech poziomach: pierwszym — pierwotnym lub naturalnym, drugim - konwencjonalnym, trzecim - wewnętrznym. Na poziomie pierwszym analiza sięga jedynie do najbardziej podstawowego postrzegania i rozumienia elementów. Poziom drugi odczytu wymaga identyfikacji i wyjaśnienia symboli, czyli interpretacji przekazu i jego znaczenia. Poziom trzeci nie tylko odbiera i interpretuje przekaz zawarty w przedstawieniu, ale także stara się zinterpretować go z historycznego punktu widzenia, poszukując społecznych i kulturowych zależności, które mogłyby poszerzyć to znaczenie ${ }^{33}$.

${ }^{30}$ Erwin PANOFSKY, Studies in Iconology: Humanistic Themes in the Art of the Renaissance (New York: Harper \& Row, 1972), 5-9.

${ }^{31}$ Bernard Berelson, Content analysis in communication research (New York: Free Press, 1952), 18; Ole R. Holsti, Content Analysis for Social Science and Humanities (Reading, MA: Addison Wesley, 1969); Klaus KRIPPENDORFF, Content Analysis: An Introduction to Its Methodology. $2^{\text {nd }}$ ed. (Thousand Oaks, CA: Sage, 2004), 413; Kimberly A. NeuENDORF, The Content Analysis Guidebook. $2^{\text {nd }}$ ed. (Thousand Oaks, CA: Sage, 2017), 17.

${ }^{32}$ KRIPPENDORFF, Content Analysis, 24.

${ }^{33}$ Anne D'Alleva, Methods \& Theories of Art History (London: Laurence King Publishers, 2012), 26-27. 
Materiał badawczy do analizy Panofsky'ego stanowią ilustracje wyselekcjonowane metodą doboru celowego ze zbioru obrazów poddanych analizie zawartości.

Zastosowane techniki służą odnalezieniu odpowiedzi na dwa postawione w niniejszym opracowaniu problemy badawcze:

- Które emocje są najczęściej komunikowane i jakie są wizualne reprezentacje emocji (wizualne słowniki emocji) towarzyszące wydarzeniom i przeżyciom kulturalnym lub dotyczącym kultury w okresie pandemii?

- Do jakich motywów społeczno-kulturowych odnosili się twórcy podczas tworzenia obrazów i jakie symbole emocji powstały w sztuce pod wpływem pandemii?

\section{ARTYSTYCZNE REPREZENTACJE EMOCJI W SZTUCE}

Współcześnie obrazy odgrywają coraz ważniejszą rolę w życiu społeczeństw. Widowiskowość i spektakularność otoczenia powodują, że zwiększa się obrazowość komunikacji społecznej. Ten swoisty „zwrot obrazowy” sprawił, że w ciągu ostatnich dwustu lat „,kultura zachodnia została zdominowana przez media wizualne w miejsce przekazów ustnych czy tekstowych",34. Obrazy przenoszą informacje, wiedzę, emocje, doznania estetyczne i wartości. Stają się przedmiotem świadomego rozszyfrowania, ale także oddziałują na podświadomość. Emocje są wywoływane przez wydarzenia i sytuacje w świecie rzeczywistym. Ważną funkcją emocji jest pobudzenie do działania przejawiającego się w konkretnych zachowaniach. Przyjmuję, że bodźce mogą być dwojakie: zewnętrzne lub wewnętrzne (inna emocja, np. strach, może wywołać złość).

\subsection{WiZUALNE REPREZENTACJE STRACHU}

W analizowanych dziełach sztuki strach najczęściej jest wywoływany przez bodziec zewnętrzy COVID-19, który jest postrzegany przez artystów głównie jako stan zagrożenia życia: sztuka ulicy (w 13 przypadkach), malarstwo (na 4 obrazach), grafika (na 3 grafikach), rysunek (na 2 rysunkach). Źródłem strachu jest tu zazwyczaj sam wirus, choć w analizowanym materiale wystąpiły też nieliczne przypadki postrzegania innych ludzi jako

${ }^{34}$ Marita Sturken i Lisa CARTwright, Practises of Looking: An Introduction to Visual Culture (Oxford: Oxford University Press, 2001), 10. 
potencjalnego zagrożenia - roznosicieli wirusa (malarstwo). Dwukrotnie odnosiło się to do zgromadzeń religijnych. Kolejnym bodźcem wywołującym strach są sytuacje postrzegane przez artystów jako nowe, np. problem z rozpoznaniem i oceną zamiarów zamaskowanych ludzi, kwarantanna postrzegana jako więzienie i zamknięte placówki kultury jako utrata środków do życia i kontaktów społecznych. Ciekawym bodźcem w malarstwie sztalugowym jest tzw. flashback, gdzie strach jest wywoływany przez powtórzenie się zjawiska z przeszłości, tu bezsilność człowieka wobec śmierci, do czego odwołuje się obraz Pietera Bruegla The Triumph of Death z 1562 r. Ostatnim z bodźców zewnętrznych jest ciemność, która towarzyszy ludziom w izolacji.

Strach może być również wywołany przez bodźce wewnętrzne, np. inne emocje lub uczucia. W materiale badawczym strach powoduje samotność, niemożliwość utrzymania bliskości fizycznej, zasady dystansu społecznego (sztuka ulicy -5 , malarstwo - 4). Na jednym z obrazów sztalugowych samotność została przedstawiona jako tonięcie.

Naturalną odpowiedzią na bodziec jest reakcja organizmu i odpowiednie zachowanie. Najliczniejszą grupę stanowią obrazy przedstawiające próbę ukrycia się przed korowirusem, uniknięcia zarażenia (sztuka ulicy - 48, malarstwo - 2). W analizowanym materiale występują dwa sposoby. Pierwszy to ukrycie ust i nosa pod maseczką chirurgiczną, a dłoni w rękawiczkach. Drugi to ukrycie się w domu w izolacji od innych ludzi i roznoszonej przez nich choroby. Kolejną grupę w materiale badawczym stanowią obrazy przedstawiające poszukiwanie wsparcia we wspólnocie (sztuka ulicy - 5, malarstwo - 2, rysunek - 1). Przede wszystkim jest to wspólnota religijna i rodzina, a $\mathrm{w}$ dalszej kolejności wspólnota narodowa lub ujęta globalnie wspólnota wszystkich ludzi ponad podziałami. Ostatnią grupą są prace, które mają za zadanie poszukiwanie pocieszenia czy też obłaskawienie COVID-19 przez jego ośmieszenie (sztuka ulicy - 2, rysunek -1).

Natężenie emocji w obrazach rozkłada się po równo pomiędzy dwie formy strachu: przerażenie (10) i niepokój (10).

Prace te mogą pełnić funkcję adaptacyjną, mającą na celu przetrwanie gatunku, ale i systemu społecznego. Na uwagę zasługują tu prace malowane dla pracowników służby zdrowia, będące swoistym hołdem dla ich zaangażowania i odwagi (sztuka ulicy -5 , malarstwo - 1, grafika - 1). Jedna z ulicznych prac oddaje hołd kasjerom, którzy podobnie jak pracownicy służby zdrowia są na pierwszej linii frontu, obsługując wielu klientów dziennie. Zapewniają o wsparciu społecznym i pokładanych w nich nadziejach członków społeczeństwa. 


\subsection{Wizualne REPREZENTACJE ZŁOŚCI}

W analizowanym materiale badawczym złość jest najczęściej wywoływana przez bodziec wewnętrzny, a więc poczucie zagrożenia zarażeniem COVID-19 (sztuka ulicy - 12, malarstwo - 5), którego molekuła na jednej z ulicznych prac została przedstawiona jako diabeł. Wśród bodźców zewnętrznych dominuje złość na izolację oraz decyzje władz ograniczające organizację wydarzeń o charakterze artystycznym i przemieszczanie (sztuka ulicy -7 , malarstwo - 4, grafika - 1). Jedna z prac, pochodząca z Somalii, podnosi kwestię stygmatyzacji ludzi w maskach. Noszący maski są tam postrzegani jako zarażeni koronawirusem i wytykani palcami, co powoduje, że ludzie nie stosują się do zaleceń władz. $Z$ drugiej strony osoby nienoszące masek są podmiotem złości gdyż ich bezmyślność może doprowadzić do wzmożonego rozprzestrzeniania się COVID-19 (sztuka uliczna - 2, malarstwo - 2). Analizowane prace (sztuka uliczna) wskazują też na Światową Organizację Zdrowia oraz Ministerstwo Zdrowia Kenii jako podmioty odpowiedzialne za nieprzygotowanie krajów rozwijających się na pandemię.

Do najczęściej przedstawianych zachowań wyrażających złość należą krzyk (sztuka ulicy - 5) oraz agresja (malarstwo - 3, sztuka ulicy - 2), przejawiająca się biciem lub kopaniem molekuły koronawirusa lub jego wyobrażeń (np. zarażonego człowieka). W jednej z prac agresja jest skierowana na komputer, na który niejako są skazani ludzie przebywający w izolacji. Pojawiają się również zaciśnięte pięści (także ręce w rękawicach bokserskich) oraz wyszczerzone zaciśnięte zęby. Zwiększona czujność, poszukiwanie zagrożenia zostało zobrazowane przez postacie z trzema parami oczu, a gotowość do walki przez rozedrganie sylwetek.

Natężenie emocji złości w analizowanych obrazach rozkłada się pomiędzy poszczególne formy emocji (gniew - 9, wściekłość - 7, irytacja - 3).

Prace te pełnią przede wszystkim funkcję mobilizacyjną, zachęcając do przestrzegania higieny, noszenia maseczek, a Światową Organizację Zdrowia oraz służby porządkowe do działania (sztuka ulicy - 7, malarstwo - 3). Dwie prace zachęcają do podjęcia twórczości artystycznej (sztuka ulicy 1 raz w materiale badawczym, grafika - także 1 raz): dekoracji maseczek, postrzeganych jako brzydkie, i rozładowywania złych emocji, frustracji poprzez sztukę, która ma działanie oczyszczające. 


\subsection{WizUALNE REPREZENTACJE SMUTKU}

W analizowanym materiale badawczym smutek wywołuje przede wszystkim bodziec wewnętrzny, a więc strach przed zarażeniem COVID-19, ponownym rozprzestrzenieniem się wirusa, niewydolnością służby zdrowia, utratą środków do życia (sztuka ulicy - 5, malarstwo - 1, grafika - 2, rysunek - 1). Strach przed drugą falą pandemii w Wuhan został namalowany na płótnie jako chaos wywołany przez samolot VN54, który przywiózł do oczyszczonego z wirusa kraju pasażera zarażonego SarsCov-2. Jedna $\mathrm{z}$ grafik obrazuje smutek $\mathrm{z}$ powodu postrzegania osób o wyraźnie azjatyckich rysach twarzy jako winnych globalnego kryzysu i przedstawia dziewczynkę w maseczce chirurgicznej, nad którą widnieje napis: „Ja nie jestem koronawirusem". Bodziec zewnętrzny to przede wszystkim utrata kontaktu z rodziną (sztuka ulicy - 1, rysunek - 1), samotność ludzi chorych w szpitalu i dystans w domu. Smutek powodowany jest też przez utratę celu, tj. pracy (sztuka ulicy - 1, grafika - 1), codziennych zajęć np. lekcji baletu (grafika - 1) oraz kontakt z kulturą online.

Wyrazem smutku w analizowanych obrazach są przede wszystkim smutne twarze, smutne oczy i płacz (sztuka ulicy -5 , malarstwo -2 , grafika -1 , rysunek - 2). Smutek dostrzec można także w braku aktywności (malarstwo -2 , grafika -1 , rysunek - 1) i izolowaniu się (malarstwo - 2, grafika - 1) lub byciu odizolowanym od innych, np. narysowaną granicą z molekuł koronawirusa. Jeden z rysunków przedstawia osobę w szpitalnej sali, która tuli się do narysowanych na ścianie sylwetek dzieci i wnuków.

Natężenie emocji smutku w analizowanych pracach rozkłada się pomiędzy formę przygnębienia (9) i żal (1).

Obrazy te komunikują, że ludzie przeżywają utratę bliskich, kontaktu z innymi ludźmi, a także czują się zagubieni, nie mogąc wykonywać swoich codziennych czynności. Bywa, że są wołaniem o pomoc (sztuka ulicy — grafika - 1). W przypadku grafiki ukazującej zmęczoną, po wielogodzinnym dyżurze, twarz lekarki z odciśniętą na oczach maską została zorganizowana sprzedaż koszulek z jej wizerunkiem i zbiórka pieniędzy na rzecz służby zdrowia w Południowej Walii. W przypadku ulicznego portretu zapłakanej kobiety $\mathrm{w}$ masce chirurgicznej stojącej obok drzwi z napisem „zamknięte” dodano napis ,potrzebna praca”. 


\subsection{WIZUALNE REPREZENTACJE RADOŚCI}

W analizowanym materiale radość jest najrzadziej występującą emocją. Powodem radości w przebadanych pracach jest zazwyczaj bodziec zewnętrzny $\mathrm{w}$ postaci poprawy sytuacji zdrowotnej w kraju lub indywidualne wyzdrowienie $\mathrm{z}$ choroby (sztuka ulicy -3 , malarstwo -1 , grafika -1 , rysunek - 1). Powodem do radości może być także praca służby zdrowia, która doprowadziła do wyleczenia pacjentów z choroby (malarstwo - 1). Pojawiają się zaskakujące rozwiązania wizualne i nowe symbole. Jedna z prac przedstawia puste łóżko szpitalne otoczone przez namalowane wokoło na ścianach sylwetki lekarzy ubranych w kombinezony, maseczki, gogle i rękawice. Nadmiar pacjentów zamienia się w nadmiar lekarzy, a kojarzące się zazwyczaj ze śmiercią puste łóżko oznacza społeczne zdrowie. Innym rodzajem bodźca zewnętrznego jest nowy temat - wyzwanie twórcze, sprowadzające się w materiale badawczym do tego, jak namalować koronawirusa $\mathrm{w}$ ulicznej galerii. Bodziec wewnętrzny to zadowolenie $\mathrm{z}$ życia (sztuka ulicy - 1, malarstwo - 1, grafika - 1), w tym z życia rodzinnego, gdyż pandemia zwróciła ludzi w kierunku takich wartości, jak życie, zdrowie, rodzina oraz twórczość jako forma wypowiedzi.

Przedstawiające radość zachowania to przede wszystkim uśmiech na twarzy (sztuka ulicy -2 , malarstwo -2 ), pocałunki (sztuka ulicy -1 , malarstwo - 1, rysunek - 1), podskoki i tańce (sztuka ulicy -1 , malarstwo - 1) oraz symbol OK (sztuka ulicy - 1).

Natężenie radości rozkłada się pomiędzy poszczególne formy emocji: satysfakcja (3), szczęście (2), nadzieja (2), duma (1).

Prace te pełnią funkcję oczyszczającą, zdrowotną, przywracającą ludzi do społeczeństwa. Uśmiechnięta twarz, swobodna postawa ciała to zachęta do wzmożonych kontaktów społecznych.

\section{SPOŁECZNO-KULTUROWE MOTYWY I SYMBOLE ZASTOSOWANE W ARTYSTYCZNYM PRZEKAZIE EMOCJI}

Przed rozwinięciem języka fonetycznego ludzie komunikowali się za pomocą symboli obrazkowych. Jest to najstarszy z systemów komunikacji międzyludzkiej, o czym świadczą gromadzone przez archeologów dzieła sztuki, dowodzące, że człowiek od niepamiętnych czasów próbował wyrażać 
w ten sposób swoje myśli i emocje ${ }^{35}$. Język sztuki kształtuje się pod wpływem kultury w konkretnych społeczeństwach, a jego oryginalne środki wyrazu wymagają często posiadania szerokiej wiedzy z zakresu kultury, która umożliwia ich prawidłowe odczytanie. Do pogłębionej analizy motywów w kontekście kulturowym wybrano prace reprezentujące sztukę ulicy, ponieważ stanowiły one najliczniejszą kategorią w analizie zawartości.

\subsection{PORTRET}

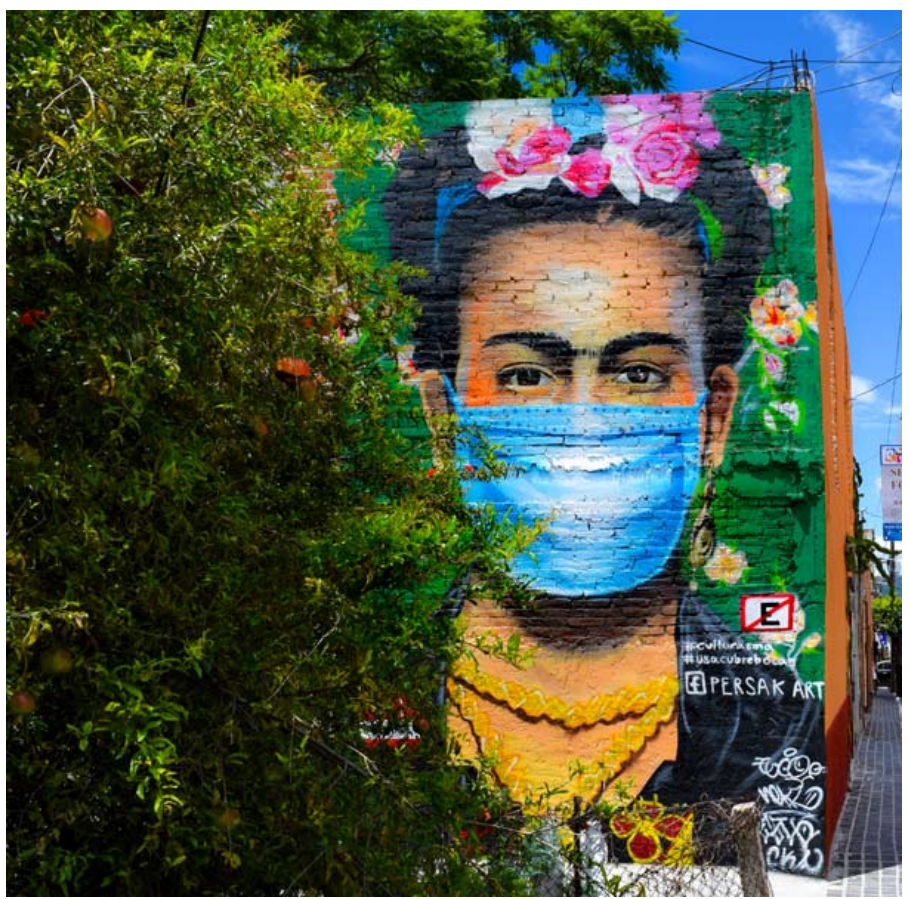

Persak Art, https://www.brooklynstreetart.com/2020/08/24/ persak-in-mexico-with-frida-says-wear-a-mask/

PozIOM PIERWSzy: Kompozycja otwarta, statyczna, prawie symetryczna. Ograniczona do odcieni zieleni paleta barwna $\mathrm{z}$ akcentem kolorystycznym w postaci niebieskiej maski chirurgicznej na twarzy kobiety i różowych kwiatów we włosach. Tło stanowi pomalowana na głęboki, butelkowy odcień zieleni ceglana ściana.

${ }^{35}$ Gerald D. Oster i Patricia Gould Crone, Using Drawings in Assessment and Therapy: A Guide for Mental Health Professionals (New York/London: Brunner-Routledge, 2004). 
Poziom DRUGi: Postać kobiety nawiązuje do portretu fotograficznego „Frida Kahlo na ławce” autorstwa Nickolasa Muraya z 1939 r., na którym artystka siedzi na białej ażurowej ławce, ubrana w czarną suknię z żółto-pomarańczowymi wzorami. W upięte warkocze Fridy wpleciono różowe róże. Wizerunek uzupełnia długi, złoty naszyjnik, sięgający do pasa malarki. Mocny makijaż artystki, strój i fryzura nawiązują do tradycji kultury meksykańskiej, w której wyrosła. Zielone tło wypełniają drobne kwiaty kwitnącej jabłoni. Zdjęcie, opublikowane pierwotnie na okładce amerykańskiego Vogue, rozpoczęło międzynarodową karierę artystki. Obraz różni się od oryginału przede wszystkim przysłaniającą usta niebieską maską chirurgiczną. W pewnym sensie stanowi ukierunkowany na twarz kadr $\mathrm{z}$ fotografii, ponieważ ubiór i tło są analogiczne. Różowe kwiaty wplecione we włosy kobiety mogą symbolizować wdzięczność i uznanie. Zielone tło kieruje odbiorcę w dwóch kierunkach: strach (rozkład, zgnilizna, trucizna) lub symbol nadziei i witalności, odradzania się kręgu życia.
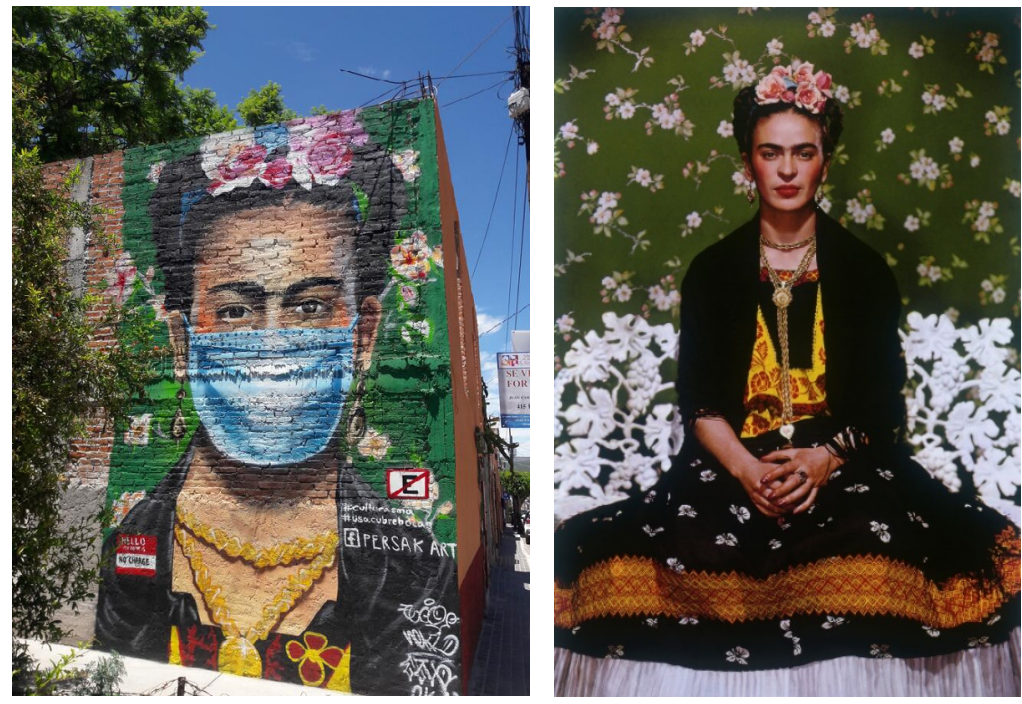

The Jacques and Natasha Gelman Collection of Mexican Art, the Vergel Foundation and the Tarpon Trust.

https://mediateka.ckzamek.pl/object/frida-kahlo-3/

Poziom trzeci: Dzieło autorstwa Persaka, a właściwie Daniela Martíneza Carrillo, które sfotografowano 20 sierpnia 2020 r. w San Miguel de Allende w Meksyku, stanowi próbę zachęty mieszkańców Meksyku do stosowania się do rządowych zaleceń dotyczących noszenia masek w miejscach publicznych, podobnie jak dwie inne prace tego artysty, przedstawiające autoportret 
Van Gogha i Mona Lisę Leonarda Da Vinci w maskach (Meksyk). Mural przedstawiający portret Fridy Kahlo zyskuje szczególne znaczenie w tej lokalizacji z dwóch powodów. Po pierwsze, ze względu na pochodzenie artystki, po drugie - ze względu na fakt, że mąż Fridy - Diego Rivera, a właściwie Diego María de la Concepción Juan Nepomuceno Estanislao de la Rivera y Barrientos Acosta y Rodríguez, meksykański malarz, grafik, architekt, był twórcą wielu meksykańskich murali.

W materiale badawczym znalazła się również maseczka odwołująca się do jednego z najbardziej znanych autoportretów Fridy Kahlo „Autoportret z cierniowym naszyjnikiem i kolibrem" z 1940 r. (olej na płótnie 63,5×49,5 cm, Kolekcja Muraya, Harry Ransom Center, Uniwersytet Teksański, Austin.

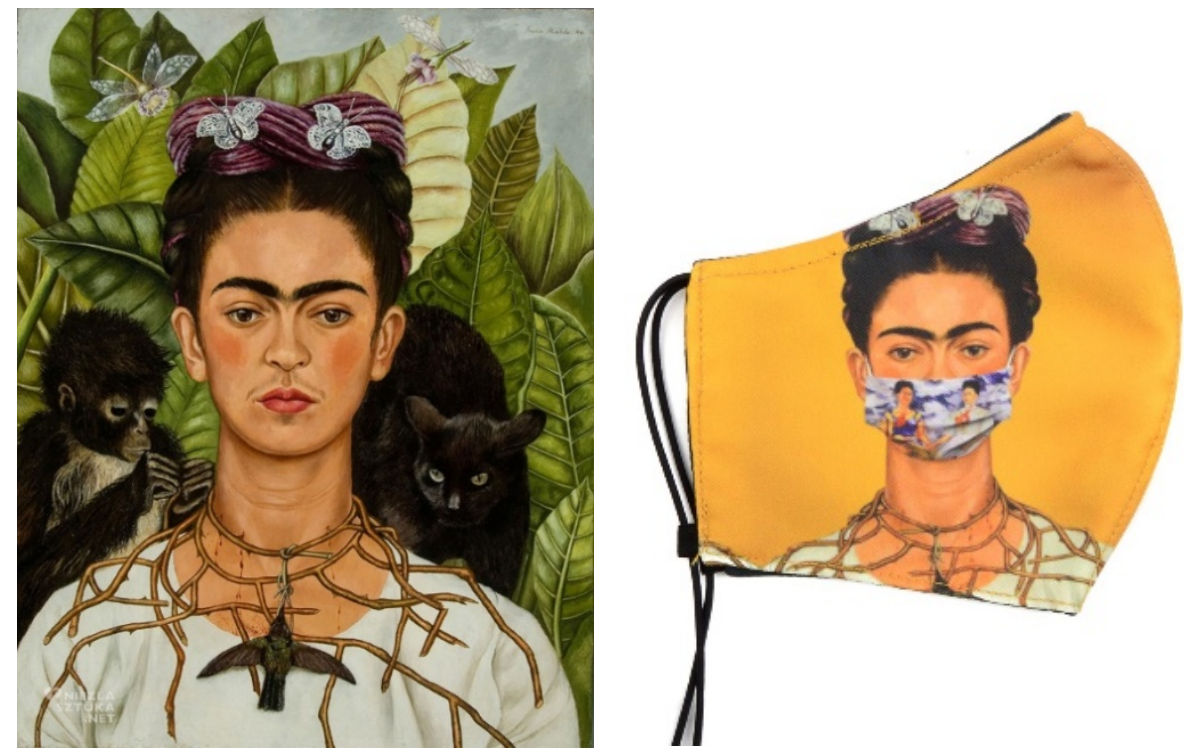

https://niezlasztuka.net/o-sztuce/frida-kahlo-autoportret-z-cierniowym-naszyjnikiem-i-kolibrem/ https://szputnyikshop.com/collections/art/products/copy-of-maszk-frida-kahlovi?variant $=36929589248160$

Obraz Fridy Kahlo to autoportret artystki. W historii sztuki wiele jest przykładów malowania przez artystów autoportretów. Wielu z nich robiło to wielokrotnie podczas swojego życia, jak choćby Albrecht Dürer czy Rembrandt. W ten sposób artyści studiowali zmiany zachodzące $\mathrm{w}$ nich pod wpływem doświadczeń życiowych, tragedii i chorób, poznawali też swoje 
własne możliwości artystyczne ${ }^{36}$. Pojawiająca się w komputerowej modyfikacji osłona ust i nosa wynika z nakazu noszenia maski w miejscach publicznych w celu ograniczenia rozprzestrzeniania się zarazków SarsCov-2 i skrywa kolejne odwołanie do twórczości Fridy Kahlo. Nawiązuje do obrazu zatytułowanego „Dwie Fridy”, samoanalizy artystycznej tożsamości rozdartej pomiędzy dwa światy. Zarówno w oryginale, jak i na masce szyja Fridy jest otoczona cierniowym pnączem, które bywa odczytywane jako nawiązanie do religii i cierpienia Chrystusa. Maska zasłoniła też charakterystyczny wyraz twarzy artystki, który nasuwa skojarzenie z Veraiconem ${ }^{37}$. Maska może wyrażać strach przed cierpieniem, rozdarciem i stanowić zapis próby ucieczki przed zagrożeniem. Z drugiej strony żółty kolor tła może budzić optymizm i zachęcać do ufnego patrzenia w przyszłość lub/i ostrzegać przed zarażeniem.

Podobne przykłady w materiale badawczym:
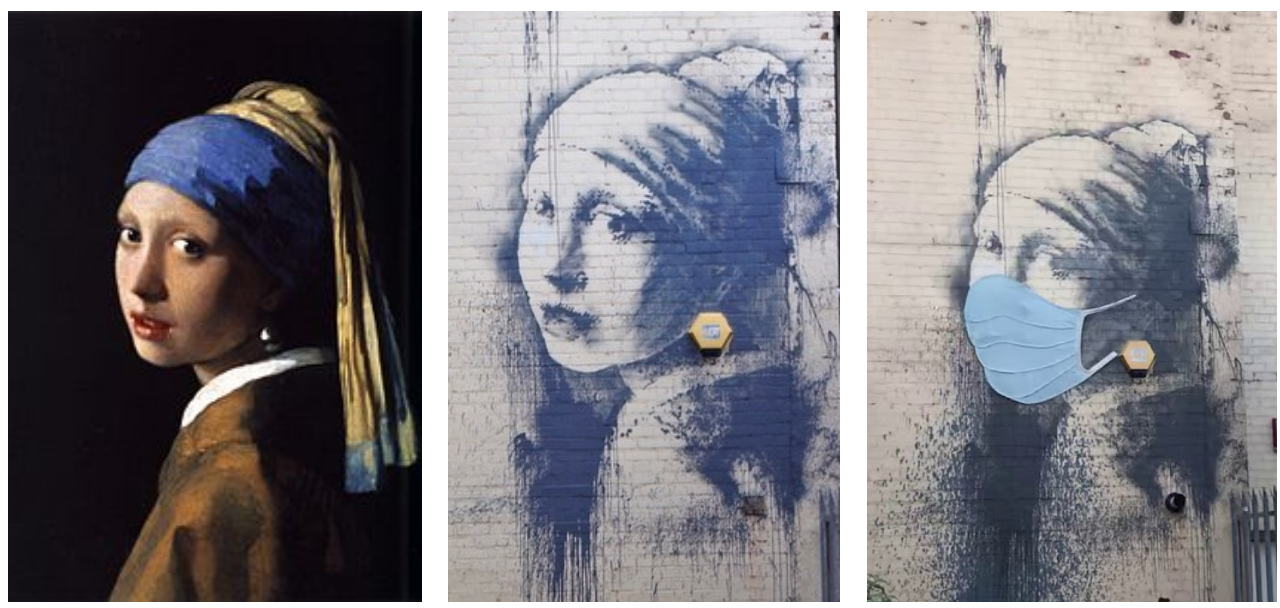

Dziewczyna z perła Johannesa Vermeera, 1664, olej na płótnie, $44,5 \times 39 \mathrm{~cm}-$ oryginał i mutacje, Mauritshuis Haga/ Banksy 2014/ Banksy 2020, Hannover Place in Bristol https://pl.wikipedia.org/wiki/Dziewczyna_z_per\%C5\%82\%C4\%85\#/media/Plik:Johannes_Vermeer_(1632-1675)__The_Girl_With_The_Pearl_Earring_(1665).jpg

${ }^{36}$ Maria RzEPIŃSKA, Siedem wieków malarstwa europejskiego (Wrocław: Zakład Narodowy im. Ossolińskich, 1986); Historia portretu. Przez sztuke do wieczności, red. Stefano Zuffi, autorzy: Matilde Battistini, Lucia Impelluso, Stefano Zuffi. Tłum. Hanna Cieśla (Warszawa: Arkady, 2001), 286.

${ }^{37}$ Motyw Veraicon odnosi się do oblicza Chrystusa odbitego na chuście św. Weroniki, gdy ocierała z potu Jego twarz w drodze na Golgotę. Halina TURSKA, „Veraicon w średniowiecznym Toruniu", Acta Universitatis Nicolai Copernici. Zabytkoznawstwo i Konserwatorstwo, nr 44 (2013): 57-73. 
https://www.cbc.ca/news/world/photos-see-wall-art-in-canada-and-around-the-world-1.5559295
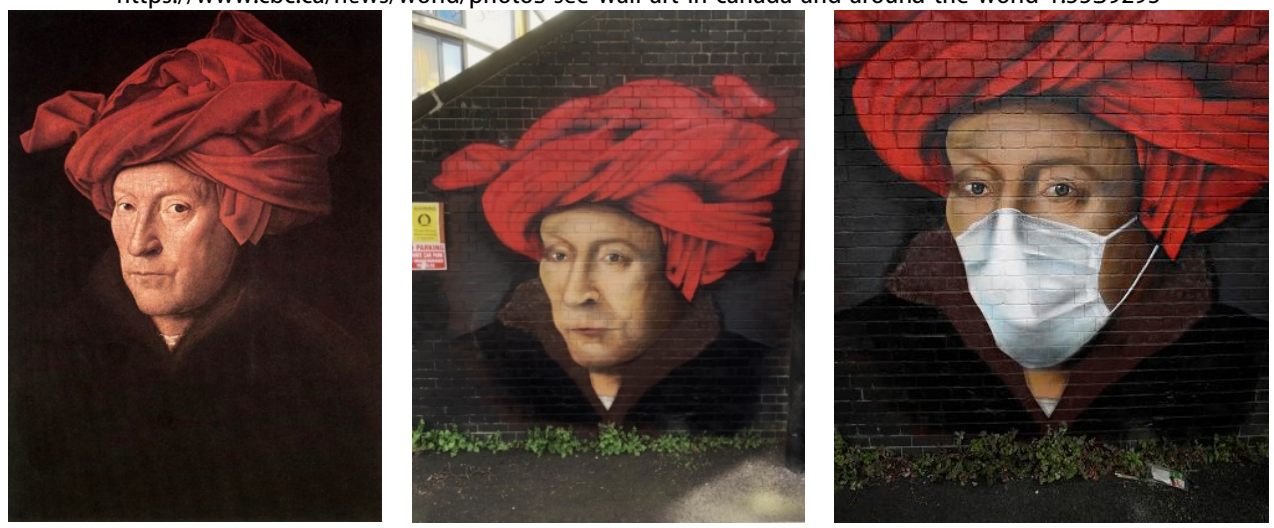

Jan van Eyck, Mężczyzna w Turbanie,1433, tempera i olej na desce dębowej, 26×19 cm oryginał i mutacje, Galeria Narodowa, Londyn / Lionel Stanhope Londyn, 2020

https://pl.wikipedia.org/wiki/Jan_van_Eyck\#/media/Plik:Portrait_of_a_Man_in_a_Turban _(Jan_van_Eyck)_with_frame.jpg http://globalstreetart.com/lionel-stanhope/

\subsection{WIECZERZA W EMAUS}

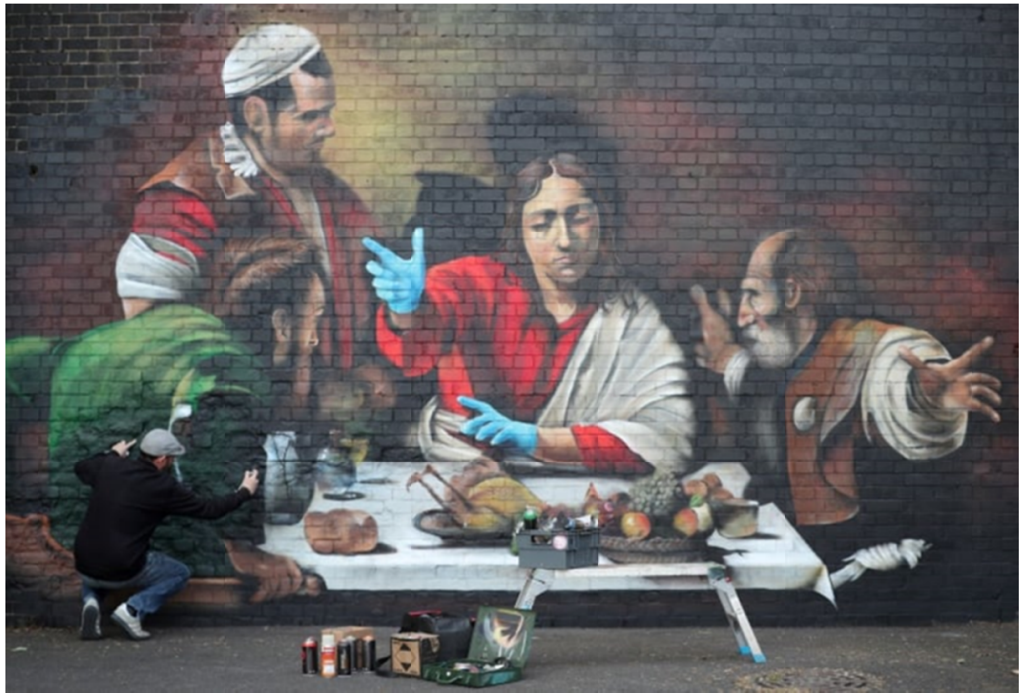

https://www.cbc.ca/news/world/photos-see-wall-art-in-canada-and-around-the-world-1.5559295, fot. Hannah McKay/Reuters

PozIOM PIERWSzY: Kompozycja otwarta, dynamiczna, asymetryczna. Bogata gama barwna w ciemnej, ciepłej tonacji, podkreśla smutek wizualizacji. Praca przedstawia czterech mężczyzn przy stole zastawionym jedzeniem, 
spożywających posiłek, światło w obrazie sugeruje wieczór, zapewne więc jest to kolacja. Niski klucz światła wzmacnia emocje strachu/smutku.

PozIOM DRUGI: Obraz mężczyzn spożywających kolację nawiązuje do obrazu Michelangela Merisi da Caravaggia pt. Wieczerza $w$ Emaus. Caravaggio namalował dwie wersje obrazu Wieczerza $w$ Emaus: 1601, olej i tempera jajeczna na desce, $141 \times 196,2 \mathrm{~cm}$, National Gallery w Londynie, oraz 1606, olej na płótnie, $141 \times 175 \mathrm{~cm}$, Pinakoteka Brera w Mediolanie.
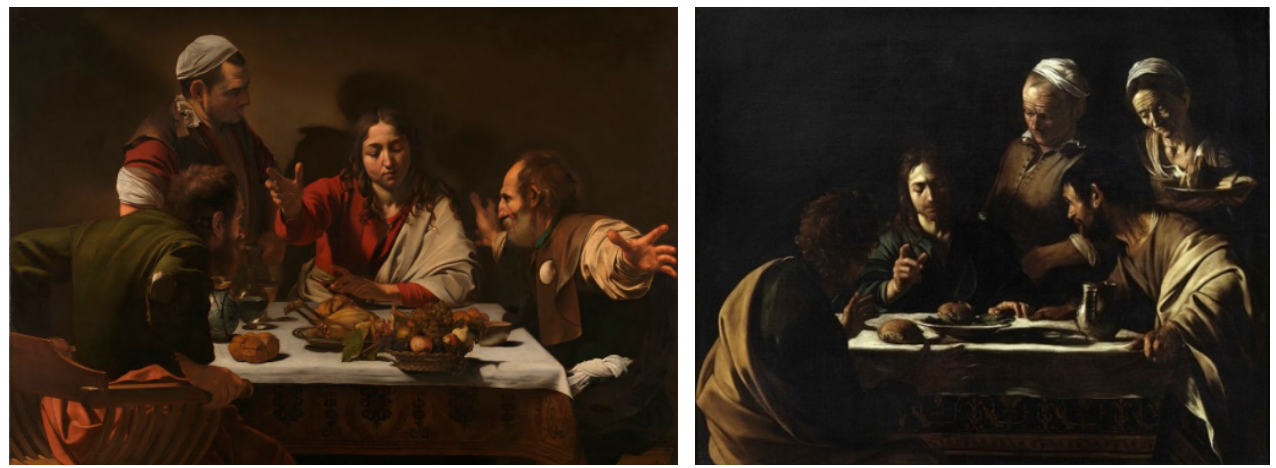

https://artsandculture.google.com/asset/supper-at-emmaus/SAEXa9MdfikXZw?hl=pl\&ms $=\% 7 \mathrm{~B} \% 22 \mathrm{x} \% 22 \% 3 \mathrm{~A} 0.5 \% 2 \mathrm{C} \% 22 \mathrm{y} \% 22 \% 3 \mathrm{~A} 0.5 \% 2 \mathrm{C} \% 22 \mathrm{z} \% 22 \% 3 \mathrm{~A} 8.643466615296521$ \%2C\%22size\%22\%3A\%7B\%22width\%22\%3A1.818090877256685\%2C\%22height \%22\%3A1.2374999999999992\%7D\%7D

Praca odwołuje się do pierwszej wersji obrazu z 1601 r. Wieczerza w Emaus odnosi się do fragmentu Ewangelii według św. Łukasza (24,13-32), opowiadającego o dwóch uczniach Jezusa, którzy trzeciego dnia po Jego śmierci udali się do wsi Emaus w pobliżu Jerozolimy, po drodze rozmawiając z przygodnym wędrowcem o męce, śmierci i zniknięciu ciała Jezusa. Dopiero podczas wspólnej wieczerzy, gdy wędrowiec błogosławił spożywany pokarm, pielgrzymi rozpoznali w nieznajomym Jezusa. Caravaggio uchwycił tę scenę z wielkim naturalizmem, łącząc ją jednocześnie ze sceną Ostatniej Wieczerzy i ustanowienia sakramentu Eucharystii. Caravaggio przedstawił pielgrzymów w znoszonych ubraniach, jeden ma przypięty do piersi symbol pielgrzyma w postaci muszli. Wyciągnięta $\mathrm{w}$ geście błogosławieństwa dłoń Jezusa i rozpostarte ramiona jednego $\mathrm{z}$ pielgrzymów ingerują $\mathrm{w}$ przestrzeń widza, nadając pracy niezwykłą dynamikę i złudzenie trójwymiarowości. Owoce w koszyku są nasycone symboliką. Winogrona symbolizują wino, a więc krew Jezusa, granaty to męczeńska śmierć, jabłka są nawiązaniem do grzechu pierworodnego, który musi zostać odkupiony męką Zbawiciela. 
POZIOM TRZECI: Uliczny obraz Stanhope'a zachowuje wszystkie elementy oryginału. Pandemia może być rozumiana jako kara za grzechy ludzkości, które po raz kolejny muszą być odkupione przez męczeńską śmierć Jezusa. Od oryginału różnią go jedynie niebieskie rękawiczki, które mają zapobiec zarażeniu COVID-19 i mogą być rozważane jako kolejny symbol, jaki pozostanie po pandemii koronawirusa. Obrazuje również poszukiwanie wsparcia w religii, modlitwie i wspólnocie religijnej.

\subsection{ANIOE}

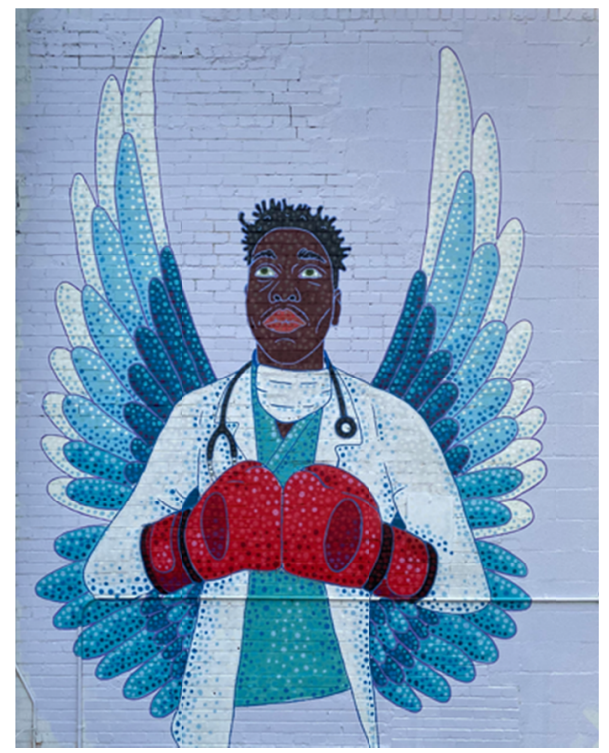

https://www.artworkarchive.com/blog/how-arts-in-health-is-persevering-during-covid

PozIOM PIERWSZY: Kompozycja otwarta, statyczna, prawie symetryczna. Kolorystyka chłodna, monochromatyczna, w tonacji błękitu z akcentem barwnym $\mathrm{w}$ postaci czerwonych rękawic bokserskich (kolor czerwony oznacza złość - moc, prowokacja, agresja). Uskrzydlony mężczyzna w stroju lekarskim, z maseczką opuszczoną pod brodę układa ręce w geście szykowania się do walki. Złość na koronawirusa i sytuację personelu medycznego stanowi motywację do walki o zdrowie obywateli. Ubiór i stetoskop to symbole związane z zawodem mężczyzny. Rękawice bokserskie i ręce zaciśnięte w pięści to symbole walki.

PozIom DRUGi: Skrzydła odnoszą się do anioła, którego pierwsze wyobrażenia istniały w starożytnym Egipcie i Babilonii. Termin „anioł” pochodzi 


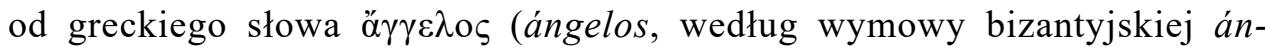
hielos), oznaczającego oryginalnie „posłańca”; po hebrajsku מלאך (mal'ach).

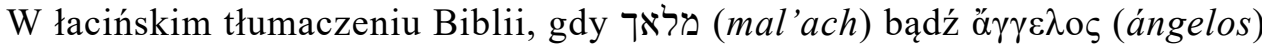
ma oznaczać posła ludzkiego, tłumacz używa słowa nuntius lub legatus, gdy zaś ma oznaczać posłańca boskiego, pojawia się słowo angelus, będące oczywiście zlatynizowaną formą gr. ó $\gamma \gamma \varepsilon \lambda o \varsigma^{38}$. Anioł jest zatem posłańcem Boga. Występuje w wielu religiach: w chrześcijaństwie, w judaizmie, w prawosławiu i w islamie. Wyobrażenia aniołów są inspirowane zarówno tekstami biblijnymi, jak i apokryficznymi. W Biblii z imienia znani są jedynie archaniołowie Gabriel, Michał i Rafał. Od początku chrześcijaństwa anioły stanowiły przedmiot rozważań Ojców Kościoła i pisarzy kościelnych. Pseudo-Dionizy Areopagita i Tomasz z Akwinu dzielili je na dziewięć chórów i trzy hierarchie. W pierwszej hierarchii mamy serafinów, cherubinów i trony. W drugiej wymieniono panowania, moce i władze. Trzecia hierarchia to zwierzchności, archaniołowie i aniołowie. Serafinów i cherubinów wyobrażano w sztuce jako uskrzydlone stworzenia o twarzach ludzkich lub zwierzęcych. Serafini i cherubini byli przedstawiani zazwyczaj z sześcioma skrzydłami, choć cherubini czasem mieli tylko cztery. Trony były wyobrażane jako istoty żyjące pełne oczu. Wyróżniają się także barwą, głównie w sztuce bizantyjskiej i włoskiej: serafini — czerwień, cherubini błękit, trony - żółć. Archaniołów ukazywano od V wieku na ogół odzianych w białe szaty, z berłem, mieczem lub kulą ziemską w dłoniach. Motyw aniołów jest stale obecny w sztuce, a ich wygląd ewoluuje zależnie od estetyki epoki. W IV wieku anioły były przedstawiane jako uskrzydlone postacie z aureolą lub w gwiaździstym diademie, a ich wygląd nawiązywał do antycznych wyobrażeń Nike i geniuszy. Gotyckie anioły mają bardziej wyeksponowane skrzydła i podkreślone cechy duchowe. W okresie renesansu anioły noszą szaty diakońskie, kapłańskie, dworskie, a także zbroje, zwłaszcza w scenach Sądu Ostatecznego. Renesans stworzył typ anioła dziewczęcego, a także dziecięcego, nawiązującego do antycznego wyobrażenia Amora. W okresie baroku szczególnie popularny był typ dziecięcy aniołów o bujnych kształtach, a także wyobrażenia samych uskrzydlonych główek ${ }^{39}$. W renesansie i baroku punkt ciężkości przesuwa się z zaświatów do tego świata, gdzie anioły pomagają ludziom, chronią ich przed złymi duchami, z którymi wciąż

${ }^{38}$ Wojciech Kosion, „Anioł w Biblii hebrajskiej. Pojęcie מלאך [mal'ach] w ujęciu statystycznym i hermeneutycznym", Studia Judaica, nr 12 (23-24) (2009): 58.

${ }^{39}$ Historia portretu. Przez sztukę do wieczności, red. Stefano Zuffi (Warszawa: Arkady, 2000); Maria RZEPIŃsKA. Siedem wieków malarstwa europejskiego (Wrocław: Zakład Narodowy im. Ossolińskich, 1986). 
prowadzą walkę. Cztery skrzydła i przewaga błękitu pozwala zakwalifikować wyobrażonego na muralu mężczyznę-anioła jako cherubina, którego zadaniem jest pomagać i chronić ludzi.

PozIOM TRZECI: Współczesne, ziemskie anioły to ludzie, którzy niosą pomoc i przywracają nadzieję. Cechuje ich wrażliwość na drugiego człowieka. Fakt, że w Denver (USA) lekarz został wyobrażony jako cherubin, podkreśla misję, jakiej podjęli się pracownicy służby zdrowia. Kolor skóry podkreśla, że walczą wszyscy, niezależnie od rasy, wyznania i kraju pochodzenia. Nie zważając na to, że mogą zostać zarażeni i przynieść chorobę do własnego domu, ratują ludzkie życie, bo ono jest wartością nadrzędną. Jawią się jako pomocnicy Boga wypełniający Jego wolę na ziemi.

Podobne przykłady w materiale badawczym:
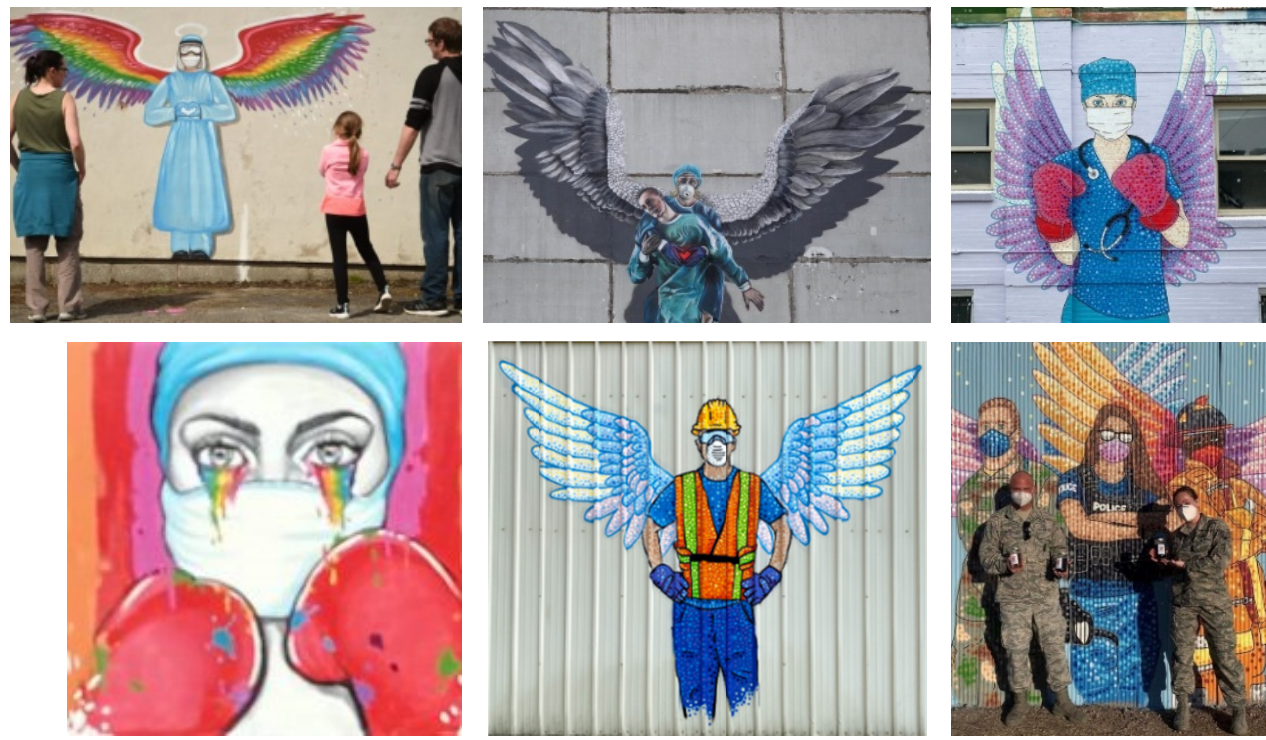

https://www.mercurynews.com/2020/04/14/photos-street-art-that-emerged-over-the-coronaviruspandemic/https://pl.pinterest.com/pin/600949144018527591/

https://matadornetwork.com/read/street-art-thanking-healthcare-workers-united-king/dom/ https://www.artworkarchive.com/blog/why-we-need-arts-in-times-of-crisis/ https://twitter.com/denverpublicart/status/1271471110375251969/ 
5.4. ATLAS

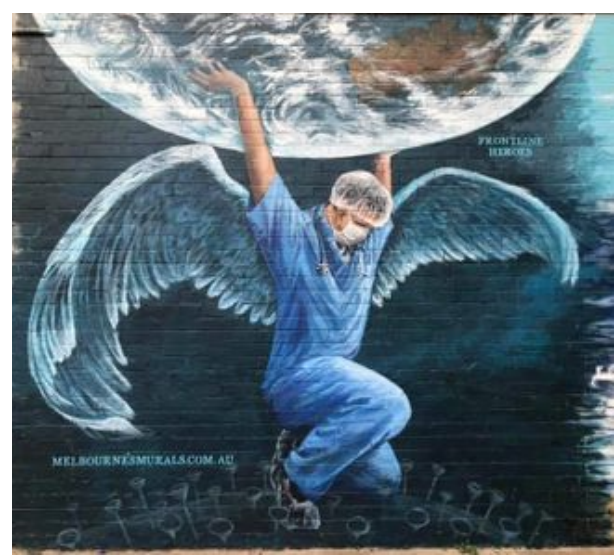

https://www.cnbc.com/2020/04/24/coronavirus-themed-muralscontinue-to-pop-up-around-the-world.html

POZIOM PIERWSZY: Kompozycja otwarta, dynamiczna, prawie symetryczna. Gama barwna wąska, zimna. Postać w uniformie, kucając, unosi w górę kulę ziemską. Tłem dla przedstawionego motywu jest błękit nieba - kolor melancholii, zadumy, refleksji, niemocy.

PozIOM DRUGi: Przedstawiona postać to lekarz ubrany w kombinezon, czepek i maskę zabezpieczające przed koronawirusem. Wokół szyi ma przewieszony stetoskop, będący symbolem wykonywanego zawodu. $\mathrm{Na}$ ramionach dźwiga ogromną kulę ziemską, przykucając na molekule wirusa COVID-19.

Motyw Atlasa, greckiego tytana podtrzymującego świat, jest powszechnie spotykanym elementem zdobniczym w Europie Środkowej.
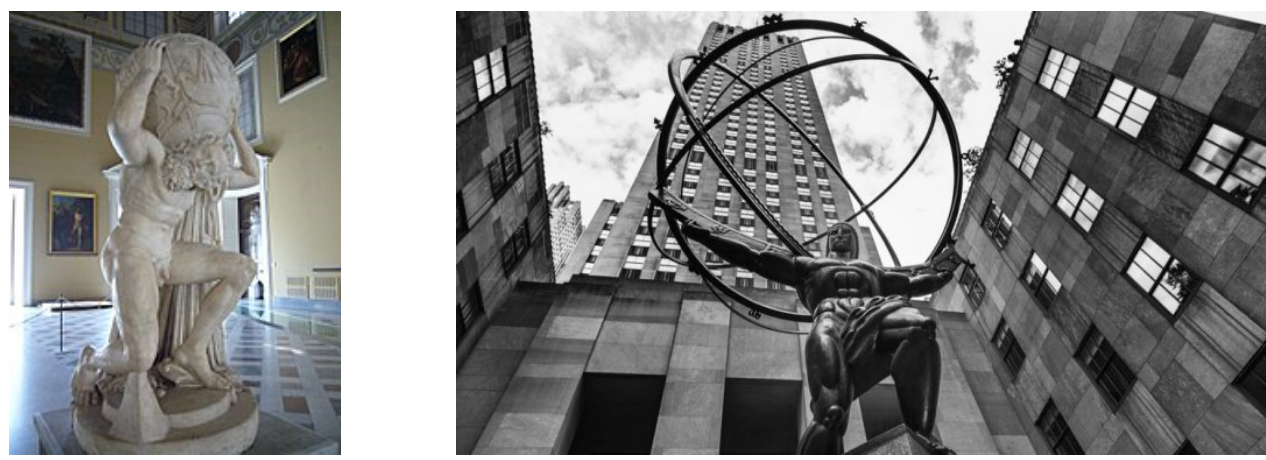

Atlas Farnezyjski, rzymska kopia z Il wieku rzeźby greckiej, Narodowe Muzeum Archeologiczne w Neapolu / Atlas, posąg z brązu, Rockefeller Center, New York, Lee Lawrie, 1937

https://pl.wikipedia.org/wiki/Atlas_Farnezyjski\#/media/Plik:MAN_Atlante_fronte_1040572.JPG /

https://www.thoughtco.com/atlas-the-greco-roman-titan-117216 
Atlas, według greckich mitów, był jednym z tytanów, synów tytana Japeta i okeanidy Klymene, bratem Prometeusza. Według innych przekazów miał być synem Uranosa, wtedy byłby zatem bratem Kronosa. Atlas należał więc do pierwszej generacji bogów - istot potwornych i gwałtownych. Wziął udział $\mathrm{w}$ przegranej walce gigantów $\mathrm{z}$ bogami olimpijskimi. Za ten bunt Zeus skazał go na wieczną pracę podtrzymywania sklepienia niebios. W tradycji greckiej widziano w Atlasie króla Arkadii, a także mitycznej Atlantydy. Uważano go za mędrca, który poznał tajemnice ciał astralnych. Wiedzę tę miał przekazać Herkulesowi. W Atlasie postrzegano także filozofa. Pierwsza literacka wzmianka o Atlasie pojawia się w Odysei Homera, następnie w Teogonii Hezjoda, a potem pisali o nim inni autorzy greccy, m.in.: Ajschylos, Sofokles, Eurypides i Platon. Wśród łacińskich autorów piszących należy wymienić Owidiusza, autora Metamorfoz, oraz Wergiliusza autora Eneidy. W ikonografii antycznej Atlas pojawia się w VI wieku p.n.e., najczęściej w kontekście mitu herkulejskiego. Tytan jest przedstawiany niemal zawsze jako dojrzały, brodaty mężczyzna stojący lub kucający, dźwigający Niebo, które trzyma oburącz na głowie lub na barkach. Niebo, które dźwiga Atlas, często jest ukazane w formie sfery, na której znajdują się ciała astralne (słońce, księżyc i gwiazdy).

Poziom tRzecr: Przedstawienie wskazuje bezpośrednio na heroizm służb medycznych zaangażowanych w walkę z pandemią SarsCov-2. Choć motyw Atlasa jest powszechnie spotykanym elementem zdobniczym w Europie Środkowej, to zaprezentowane wyobrażenie powstało w Melbourne w Australii 12 maja 2020 r., po pierwszej fali pandemii. W sierpniu i wrześniu Melbourne, stolica stanu, przez wiele tygodni było objęte ścisłym reżimem kwarantanny. Mural nobilituje służby, które przyjęły na siebie część obowiązków, podkreślając, że w obliczu kryzysu najważniejsza jest spójność społeczna i wzajemne wsparcie. Sięgając do motywów mitologicznych, podkreśla także, że Ziemia ma dłuższą historię niż ludzkość. Ludzie powinni pamiętać, że sami są odpowiedzialni za obecne wydarzenia i muszą wziąć za nie odpowiedzialność. Pandemie zdarzały się już wcześniej i będą miały miejsce w przyszłości. Pomiędzy tradycyjną wersją motywu Atlasa a interpretacją artystów z Australii widoczną różnicą jest zamiana globu pod stopami lekarza na molekułę COVID-19 - symbol wirusa oraz maska chirurgiczna. Atlasowi dodano też charakterystyczne skrzydła, a kolorystyka przedstawienia wskazuje na istnienie równolegle motywu religijnego anioła cherubina.

Podobny motyw w materiale badawczym: 

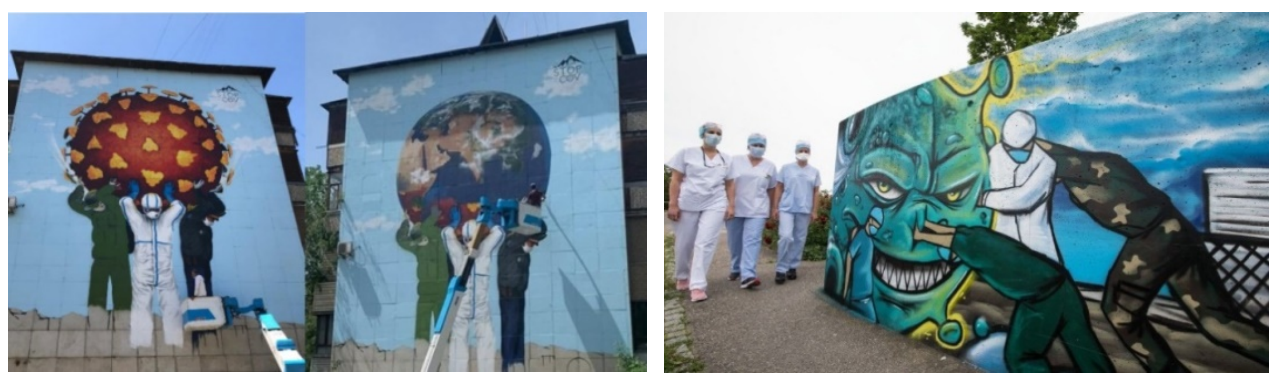

https://theworldnews.net/tj-news/murals-expressing-gratitude-to-frontline-workers -spark-intense-art-debate-in-kazakhstan

https://www.rp.pl/Prawo-karne/305279973-Koronawirus-atak-na-lekarza-ratownika-i-gornika -traktowany-jak-stalking.html

\subsection{Superbohater}

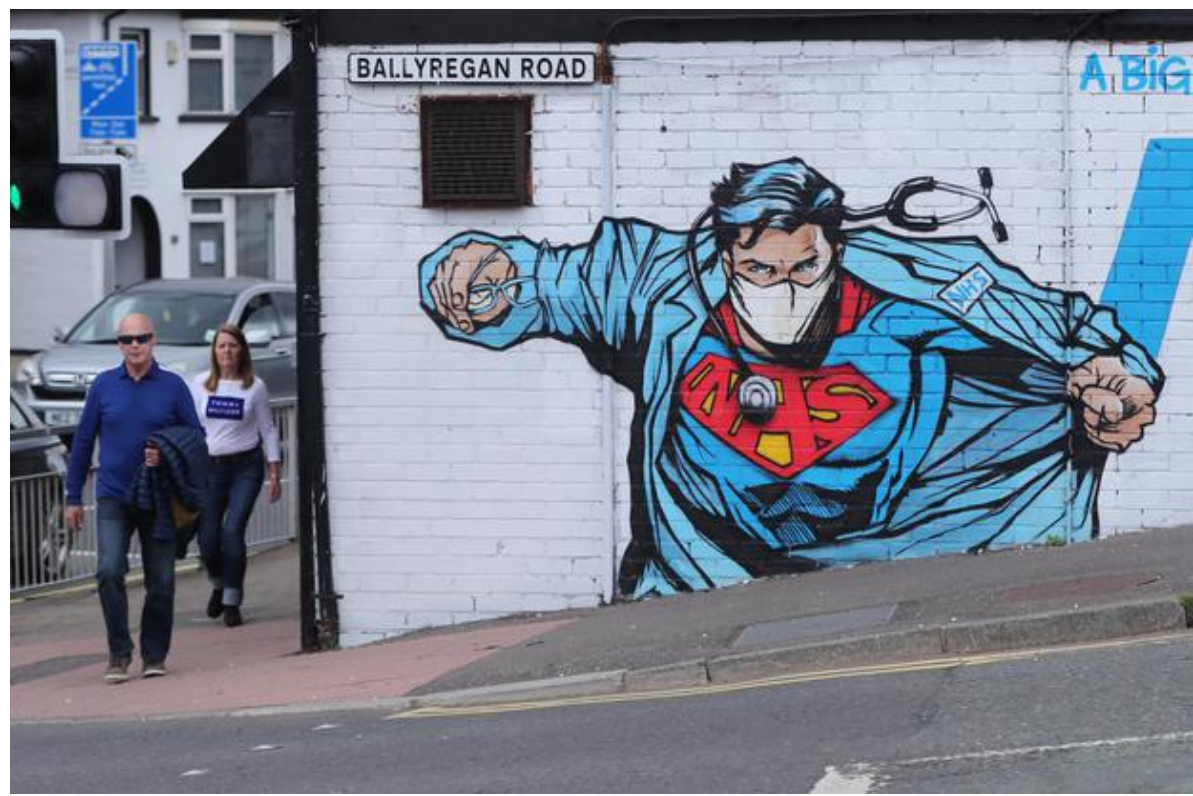

https://www.belfasttelegraph.co.uk/opinion/viewpoint/the-nhs-is-crucialnow-more-than-ever-39666339.html

POZIOM PIERwSZY: Kompozycja otwarta, dynamiczna, asymetryczna, Żywa kolorystyka z przewagą czystego koloru - błękit jest kolorem firmamentu, dlatego też jest symbolem nieba, powietrza, odwagi lub też melancholii i niemocy. Na pierwszym planie mężczyzna w maseczce gwałtownym gestem zdziera ubranie. 


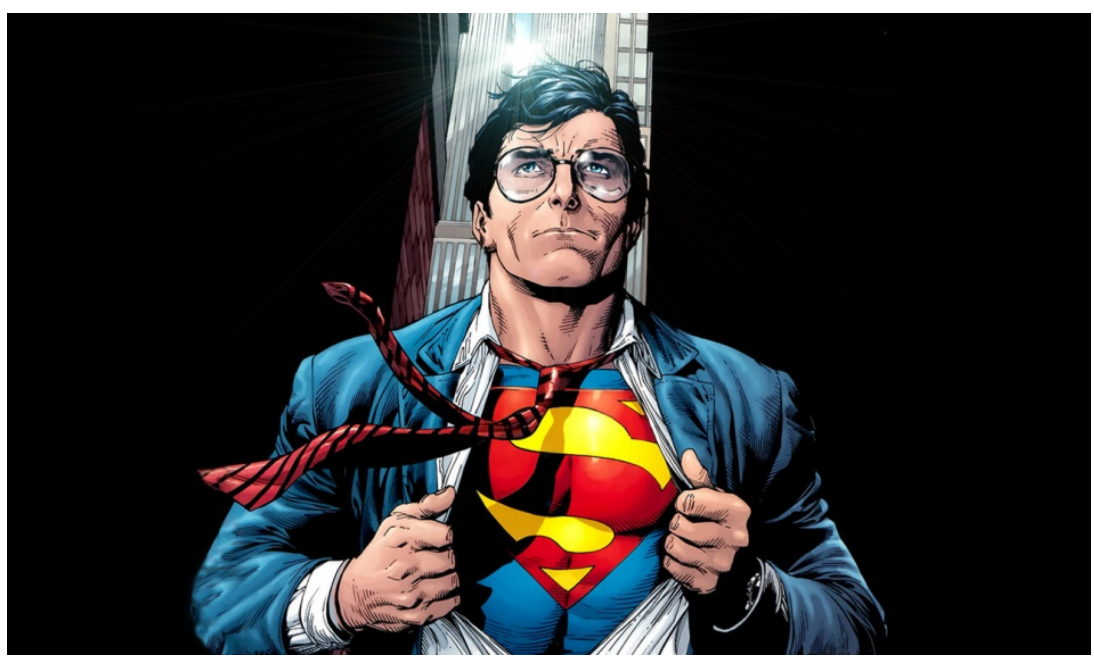

https://lekturaobowiazkowa.pl/komiksy/dlaczego-nikt-wiedzial-ze-clark-kent-superman/

PozIOM DRUGI: Kruczoczarne włosy i atletyczna budowa ciała, charakterystyczne okulary i strój widoczny pod rozpiętym kitlem pozwalają zidentyfikować postać jako Clarka Kenta — Supermana. Charakterystyczny jest też gest zdejmowania okrycia wierzchniego przed akcją.

Superman to fikcyjna postać (superbohater), znany z serii komiksów wydawanych przez DC Comics oraz wielu adaptacji filmowych związanych z tą postacią. Został stworzony przez Joe Shustera i Jerry'ego Siegela ${ }^{40}$. Po raz pierwszy pojawił się w magazynie Action Comics vol. 1 \#1 (czerwiec 1938 r.) ${ }^{41}$. Postać superbohatera początkowo czerpała wzorce z koncepcji nadczłowieka (niem. Übermensch), opisanej przez Friedricha Nietzschego ${ }^{42}$. Później jednak Siegel i Shuster postanowili uczynić z tej postaci herosa, przy którego kreacji dużą rolę odegrała fantastyczno-naukowa powieść Philipa Wylie'a Gladiator z 1930 r. Twórcy czerpali również natchnienie z judaizmu i mitologii greckiej ${ }^{43}$. W pierwszym przypadku protoplastą postaci był Mojżesz

${ }^{40}$ David Colton, „The crime that created Superman. Did fatal robbery spawn Man of Steel?” USA Today z 26.08.2008, dostęp 26.08.2008, https:/usatoday30.usatoday.com/life/books/news/ 2008-08-25-superman-creators_N.htm.

${ }^{41}$ Action Comics. Dostęp 06.11.2020. https://dc.fandom.com/wiki/Action_Comics_Vol_1_1.

${ }^{42}$ Friedrich Nietzsche, Tako rzecze Zaratustra, thum. Wacław Berent (Toruń/Warszawa/ Siedlce: Towarzystwo Wydawnicze „IGNIS“ S.A., 1922).

${ }^{43}$ Danny Fingeroth, Superman on the Couch: What Superheroes Really Tell Us about Ourselves and Our Society (New York: Continuum/London: Bloomsbury Academic, 2004); Simcha Weinstein, „Superman: From Cleveland to Krypton. The Man of Steel's Jewish roots”, My Jewish learning, dostęp 12.05.2021, https://www.myjewishlearning.com/article/supermanfrom-cleveland-to-krypton/. 
i idea zbawiciela, pochodzącego $\mathrm{z}$ niemal wymarłego ludu, w drugim Samson i Herakles, bohaterowie, dokonujący czynów niewykonalnych dla zwykłego śmiertelnika. Kryptońskie nazwisko Clarka Kenta brzmi KalEl (oryg. Kal-L), co odnosi się do hebrajskiego „głos Boga”44. Sam przyrostek -El jest w rzeczywistości nazwiskiem rodowym i pochodzi od semickiego słowa „El”, oznaczającego właśnie boga ${ }^{45}$. Postać Supermana jest obdarzona nadludzkimi zdolnościami ${ }^{46}$, dzięki którym jest $\mathrm{w}$ stanie nieść pomoc ludzkości, stawać w obronie słabszych i uciśnionych. Superman nosi niebiesko-czerwony kostium z peleryną, przypominający strój cyrkowego siłacza. Na piersi ma charakterystyczny symbol - czerwoną, łacińską literę „S”, wpisaną w przypominającą diament żółtą tarczę. Superman jest obok Batmana i Spidermana jedną z najbardziej rozpoznawalnych postaci komiksowych. Jako przybysz z innej planety, stanowi odzwierciedlenie przedstawiciela obcej kultury, imigranta, który zaaklimatyzował się w amerykańskim społeczeństwie, podobnie jak jego twórcy, których wyróżniała religia i pochodzenie.

PozIOM TRZECI: Epidemia zakaźnej choroby COVID-19 wywoływanej przez wirusa SARS-CoV-2 rozpoczęła się w listopadzie 2019 r. w mieście Wuhan, w prowincji Hubei, w środkowych Chinach. W marcu 2020 r. została uznana przez Światową Organizację Zdrowia (WHO) za pandemię. W okresie od listopada 2019 do stycznia 2020 r. zachorowania pojawiały się głównie w mieście Wuhan, ale już w połowie stycznia wirus rozprzestrzenił się w całych Chinach. W drugiej połowie lutego ogniska zakażeń pojawiły się w Korei Południowej, we Włoszech oraz w Iranie. W marcu 2020 r. WHO podała, że epicentrum pandemii koronawirusa stała się Europa (MJM, 2020). Chorzy zarejestrowani zostali na wszystkich kontynentach z wyjątkiem Antarktydy. Do maja 2021 r. odnotowano 167591800 przypadków zachorowań i 3479829 zgonów na COVID-19. Do zwalczenia pandemii o takiej sile i z taką liczbą ofiar śmiertelnych na całym świecie konieczne wydają się nadludzkie moce, ponieważ służba zdrowia w wielu krajach jest w bardzo słabej kondycji. Mural powstał w pobliżu szpitala Ulster na obrzeżach

${ }^{44}$ Umberto Eco, Superman $w$ literaturze masowej. Powieść popularna: między retoryka a ideologia, thum. Joanna Ugniewska (Warszawa: Państwowy Instytut Wydawniczy, 1996); Tomasz PsTRĄGOWSKI, „Superman skończył 75 lat”, dostęp 22.08.2013, komiksomania.pl, 3.

${ }^{45}$ Jakub „EL-Kal” KoIsz. „Superman a religia”. KZ. Magazyn Miłośników Komiksu, nr 56 (2009), dostęp 24.04.2021, https://www.kzet.pl/2009_02/m_superman.htm.

${ }^{46} \mathrm{~W}$ skład tych boskich mocy wchodzą: nadludzka siła, nadludzka kondycja, nadludzka szybkość, latanie, niezniszczalność, nadludzki oddech, oddech zamrażający, wzrok termiczny, wyostrzone zmysły. 
Belfastu jako wyraz wsparcia dla National Health Service (NHS ${ }^{47}$ na granicy brexitu. Na trudną sytuację pandemiczną w Irlandii Północnej nałożyły się tu kwestie związane z gorącymi dyskusjami nad zjednoczeniem Irlandii Północnej i Południowej, która dotychczas w całości była krajem UE. Analizowany mural wyraża dumę z pracowników służby zdrowia, wdzięczność za ich trud i zaangażowanie. Ma podnosić morale i motywować do noszenia maseczek i przestrzegania zasad dystansu społecznego.

To, co odróżnia wizualizację od oryginału, to maska chirurgiczna, przerobione liternictwo i treść w symbolu Supermana (zamiast S - NHS).

Podobne w materiale badawczym:
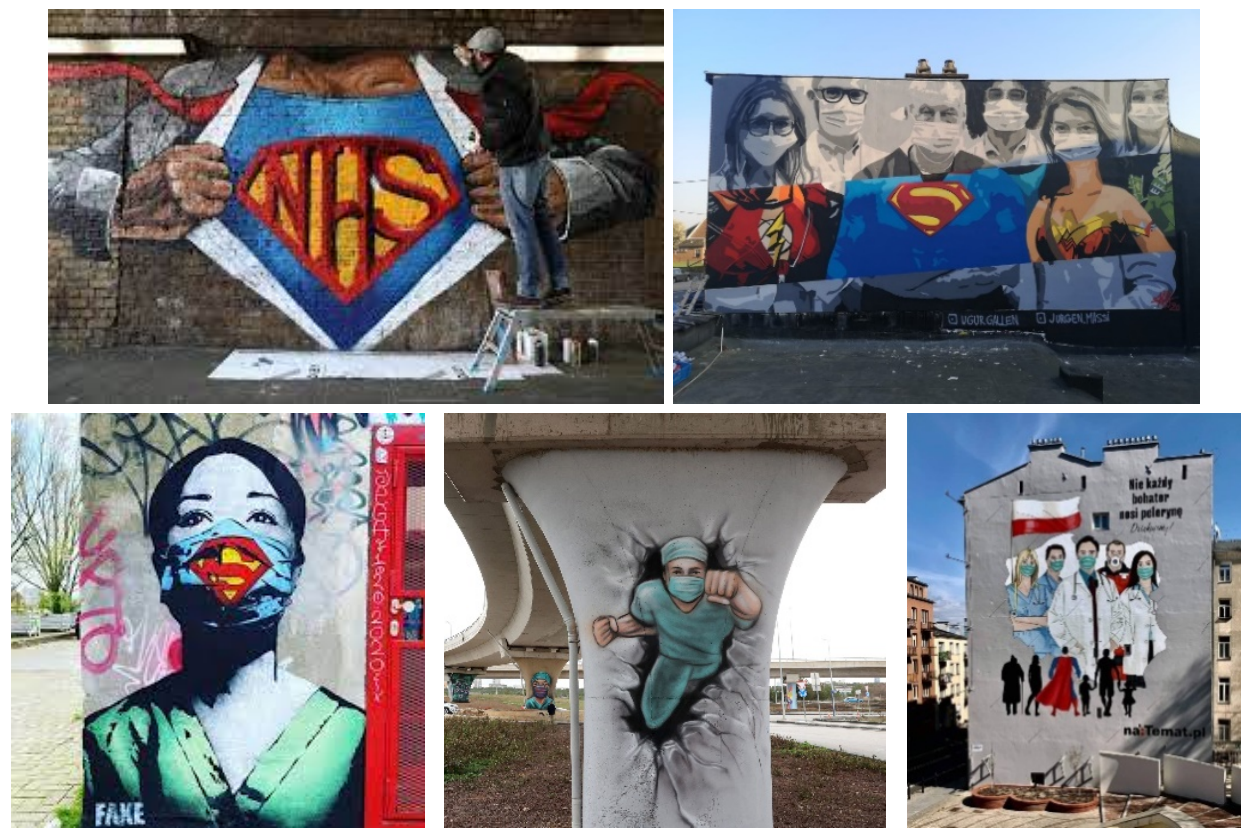

https://developmentdispatch.com/covid-19-africa-roundup-week-ending-31-may-

2020/https://eu.usatoday.com/picture-gallery/news/world/2020/03/24/coronavirus-inspires-worldgraffiti/2910639001/https://www.graffitistreet.com/street-art-murals-in-response-to-the-covid19-pandemic2020/https://twitter.com/pia_raben/status/1250431049063993349

Opisane w podrozdziale motywy, takie jak portret, Wieczerza w Emaus, anioł, Atlas czy Superbohater, nie wyczerpują listy wszystkich motywów, jakie pojawiły się w materiale badawczym, lecz stanowią ich próbkę. Do

${ }^{47}$ Wspólna nazwa dla trzech z czterech systemów służby zdrowia w Wielkiej Brytanii, finansowanych ze środków publicznych. Stosowane są też nazwy NHS Scotland (Szkocja) i NHS Wales (Walia). Dla oznaczenia Health and Social Care in Northern Ireland (Służby Zdrowia i Opieki Społecznej w Irlandii Północnej) dużo częściej stosowany jest skrót HSC, rzadziej - NHS. 
najciekawszych należy też motyw matki czy emotikona, ale opisanie wszystkich nie jest możliwe ze względu na ograniczoną objętość publikacji, jaką jest artykuł.

\section{PODSUMOWANIE}

W analizowanym materiale badawczym wystąpiły wszystkie emocje podstawowe wymieniane przez Paula Ekmana, choć w różnym natężeniu, np. wstręt pojawił się marginalnie, został więc pominięty.

Emocją najczęściej występującą w przekazach artystycznych umieszczonych w Internecie był strach (pojawia się 31 razy). Wywoływany jest przez bodziec zewnętrzy COVID-19, który jest postrzegany przez artystów głównie jako stan zagrożenia życia (22). Źródłem strachu jest tu zazwyczaj sam wirus, choć w analizowanym materiale wystąpiły też nieliczne przypadki postrzegania jako potencjalnego zagrożenia innych ludzi - roznosicieli wirusa. Strach może być również wywołany przez bodźce wewnętrzne, np. inne emocje lub uczucia (9). W materiale badawczym strach powoduje samotność, niemożliwość utrzymania bliskości fizycznej, zasady dystansu społecznego. Najczęstszą reakcją była chęć odizolowania od źródła zakażenia, próba ukrycia się przed koronawirusem, uniknięcia zarażenia. W analizowanym materiale występują dwa sposoby. Pierwszy z mnich to ukrycie ust i nosa pod maseczką chirurgiczną, a dłoni w rękawiczkach. Drugi to ukrycie się w domu w izolacji od innych ludzi i roznoszonej przez nich choroby.

Druga pod względem liczebności w materiale badawczym jest złość (29). Najczęściej wywoływana jest przez bodziec wewnętrzny (17), a więc poczucie zagrożenia zarażeniem COVID-19, którego molekuła na jednej z prac została przedstawiona jako diabeł. Wśród bodźców zewnętrznych (12) dominuje złość na izolację oraz decyzje władz ograniczające organizację wydarzeń o charakterze artystycznym i przemieszczanie. Do najczęściej przedstawianych zachowań wyrażających złość należą krzyk oraz agresja, przejawiająca się biciem lub kopaniem molekuły koronawirusa bądź jego wyobrażeń (np. zarażonego człowieka). Wystąpiła także agresja skierowana na technologie (np. komputer).

W analizowanym materiale badawczym smutek występuje dużo rzadziej (13). Wywołuje go przede wszystkim bodziec wewnętrzny (9), a więc strach przed zarażeniem COVID-19, ponownym rozprzestrzenieniem się wirusa, niewydolnością służby zdrowia, utratą środków do życia. Bodziec zewnętrzny (4) 
to przede wszystkim utrata kontaktu z rodziną, samotność ludzi chorych w szpitalu i dystans w domu. Wyrazem smutku w analizowanych obrazach są przede wszystkim smutne twarze i smutne oczy i płacz. Smutek można dostrzec także w braku aktywności (np. leżeniu w samotności) i izolowaniu się lub byciu odizolowanym od innych, np. granicą z molekuł koronawirusa.

Emocją najrzadziej występującą $\mathrm{w}$ analizowanym materiale badawczym jest radość (10). Powodem radości w przebadanych pracach jest zazwyczaj bodziec zewnętrzny (7) w postaci poprawy sytuacji zdrowotnej w kraju lub indywidualne wyzdrowienie $\mathrm{z}$ choroby. Powodem do radości może być także praca służby zdrowia, która doprowadziła do wyleczenia pacjentów z choroby. Innym rodzajem bodźca zewnętrznego jest nowy temat, wyzwanie twórcze, sprowadzające się w materiale badawczym do tego, jak namalować koronawirusa. Bodziec wewnętrzny (3) to zadowolenie z życia, w tym z życia rodzinnego, gdyż pandemia zwróciła ludzi w kierunku takich wartości, jak życie, zdrowie, rodzina oraz twórczość jako forma wypowiedzi. Przedstawiające radość zachowania to przede wszystkim uśmiech na twarzy, pocałunki, podskoki i tańce oraz symbol OK.

Emocje wyrażane poprzez sztukę pełnią różne funkcje: adaptacyjną, obronną (motywacyjną), informacyjną, oczyszczającą (zdrowotną). Naczelną funkcją wydaje się jednak funkcja oczyszczająca rozumiana jako katharsis, umożliwiająca usunięcie negatywnych emocji z organizmu poprzez przeżycie artystyczne zarówno po stronie artysty, jak i odbiory dzieła sztuki.

Uliczni twórcy dzieł sztuki odwoływali się do bardzo różnorodnych motywów: religijnych, mitologicznych oraz pochodzących z kultury popularnej. Analiza materiału badawczego wykazała, że w przestrzeni społecznej i kulturze pojawiły się nowe symbole reprezentujące pandemię SARSCov-2: molekuła koronawirusa (symbol uniwersalny emocjonalnie) oraz biała lub niebieska maska chirurgiczna i lateksowe rękawiczki symbolizujące strach.

\section{BIBLIOGRAFIA}

Action Comics. Dostęp 06.11.2020. https://dc.fandom.com/wiki/Action_Comics_Vol_1_1. Bellantoni, Patti. Jeśli to fiolet, to ktoś umrze: teoria koloru w filmie. Tłum. Monika Dańczyszyn. Warszawa: Wydawnictwo Wojciech Marzec, 2010.

Berelson, Bernard. Content analysis in communication research. New York: Free Press, 1952.

BocıEK, Beata. „Naturalne i nadprzyrodzone znaczenie symboliki światła w malarstwie okresu baroku". Studia Elbląskie, t. 12 (2011): 409-424. 
Colton, David. „The crime that created Superman. Did fatal robbery spawn Man of Steel?" USA Today z 26.08.2008. Dostęp 26.08.2008, https://usatoday30.usatoday.com/life/books/news/ 2008-08-25-superman-creators_N.htm.

CZYŻEwSKI, Stefan, i Piotr SitARSKI. „Słownik pojęć filmowych”. Edukacja filmowa. Dostęp 14.04.2020. http://edukacjafilmowa.pl/abc-filmu/.

D’Alleva, Anne. Methods \& Theories of Art History. London: Laurence King Publishers, 2012.

ECO, Umberto. Superman w literaturze masowej. Powieść popularna: między retoryka a ideologia. Tłum. Joanna Ugniewska. Warszawa: Państwowy Instytut Wydawniczy, 1996.

EkMAn, Paul. „Wszystkie emocje są podstawowe”. W: Natura emocji. Podstawowe zagadnienia. Red. Paul Ekman, Richard J. Davidson. Tłum. Bogdan Wojciszke. Gdańsk: GWP, 1998.

Eurostat. Statistics Explained. Dostęp 24.07.2020. https://ec.europa.eu/eurostat/statistics explained/.

FINGEROTH, Danny. Superman on the Couch: What Superheroes Really Tell Us about Ourselves and Our Society. New York: Continuum/London: Bloomsbury Academic, 2004.

GAGE, John. Kolor i kultura. Teoria i znaczenie koloru od antyku do abstrakcji. Tłum. Joanna Holzman. Kraków: Universitas, 2008.

GeERTZ, Clifford. Interpretacja kultur. Wybrane eseje. Tłum. Maria Piechaczek. Kraków: Wydawnictwo Uniwersytetu Jagiellońskiego, 2005.

Google. Arts and Culture. Dostęp 06.11.2020. https://artsandculture.google.com/.

GotTschalk, H.B.: „The 'Decoloribus' and Its Author”. Hermes, t. 92 (1964): 59-85.

Heller, Eva, i Joaquín Chamorro Mielke. Psicología del color: cómo actúan los colores sobre los sentimientos y la razón. Barcelona: Gustavo Gili, 2017.

Historia portretu. Przez sztukę do wieczności. Red. Stefano Zuffi. Autorzy: Matilde Battistini, Lucia Impelluso, Stefano Zuffi. Tłum. Hanna Cieśla. Warszawa: Arkady, 2001.

Holsti, Ole R. Content Analysis for Social Science and Humanities. Reading, MA: Addison Wesley, 1969.

IZARD, Carroll E. The face of emotion. Century psychology series. New York: Appleton-CenturyCrofts, 1971.

JASIELSKA, Aleksandra. „Reprezentacja współczesnych modeli emocji w dziełach sztuki”. Teksty Drugie, z. 6 (2013 ): 205-221.

Jennings, Lee Byron. „Termin 'groteska””. Tłum. Maria Bożenna Fedewicz. W: Groteska. Seria: Tematy teoretyczno-literackie. Red. Michał Głowiński, 31-53. Gdańsk: słowo/ obraz terytoria, 2003.

KoIsZ, Jakub „EL-Kal”. „Superman a religia”. KZ. Magazyn Miłośników Komiksu, nr 56 (2009). Dostęp 24.04.2021, https://www.kzet.pl/2009_02/m_superman.htm.

KopALIŃSKI, Władysław. Słownik symboli. Warszawa: Oficyna Wydawnicza RYTM 2012.

Kosior, Wojciech. „Anioł w Biblii hebrajskiej. Pojęcie מלאך [mal'ach] w ujęciu statystycznym i hermeneutycznym". Studia Judaica, nr 12 (23-24) (2009): 57-79.

KrippendorfF, Klaus. Content Analysis: An Introduction to Its Methodology. $2^{\text {nd }}$ ed. Thousand Oaks, CA: Sage, 2004.

Krotz, Friedrich. Die Mediatisierung kommunikativen Handels. Der Wandel von Alltag und sozialen Beziehungen, Kultur und Gesellschaft durch die Medien. Wiesbaden: Westdeutscher Verlag, 2007.

Mazela, Anna. „Surrealistyczne wizje lęku w fotografiach Kaveha Hosseiniego”. W: Anatomia strachu. Strach, lęk i ich oblicza we wspótczesnej kulturze. Red. Bogusława Bodzioch-Bryła 
i Lilianna Dorak-Wojakowska. Kraków: Wydawnictwo Naukowe Akademii Ignatianum w Krakowie, 2017.

NeuEndorf, Kimberly A. The Content Analysis Guidebook. $2^{\text {nd }}$ ed. Thousand Oaks, CA: Sage, 2017.

NĘCKI, Zbigniew, Izabela Sowa i Jerzy Rosiński. „Psychologia reklamy”. W: Ze świata reklamy. Red. Andrzej S. Barczak i Andrzej Pitrus. Kraków: Wydawnictwo Uniwersytetu Jagiellońskiego, 1999.

NiETZSCHE, Friedrich. Tako rzecze Zaratustra. Tłum. Wacław Berent. Toruń/Warszawa/Siedlce: Towarzystwo Wydawnicze „IGNIS“ S. A., 1922.

Ocula Magazine. Dostęp 06.11.2020. https://ocula.com/magazine/art-news/interest-in-google-artsculture-skyrockets-as/

Oster, Gerald D., i Patricia Gould Crone. Using Drawings in Assessment and Therapy: A Guide for Mental Health Professionals. New York/London: Brunner-Routledge, 2004.

PANOFSKY, Erwin. Studies in Iconology: Humanistic Themes in the Art of the Renaissance. New York: Harper \& Row, 1972.

Polony, Leszek. Symbol i muzyka. Kraków: Akademia Muzyczna, 2011.

REYKOWSKI, Janusz. Eksperymentalna psychologia emocji. Warszawa: Książka i Wiedza, 1974.

RZEPIŃSKA, Maria. Historia koloru w dziejach malarstwa europejskiego. Kraków: Wydawnictwo Literackie, 1983.

RZEPIŃSKA, Maria. Siedem wieków malarstwa europejskiego. Wrocław: Zakład Narodowy im. Ossolińskich, 1986.

Skowronek, Bogusław. „Ciało, emocje, rozum. Raz jeszcze o mechanizmach odbioru filmu”, Annales Universitatis Mariae Curie-Sklodowska. Sectio N, Educatio Nova, vol. 2 (2017): 163-174.

Sturken, Marita, i Lisa Cartwright. Practises of Looking: An Introduction to Visual Culture. Oxford: Oxford University Press, 2001.

SzTOMPKA, Piotr. Socjologia. Kraków: Znak, 2002.

TAN, Ed S. „Film fabularny jako maszyna emocji”, w: Kognitywna teoria filmu. Antologia przekładów, red. Jacek Ostaszewski, 248-276. Kraków: Wydawnictwo Baran i Suszczyński, 1999.

TURSKA, Halina. „Veraicon w średniowiecznym Toruniu”. Acta Universitatis Nicolai Copernici. Zabytkoznawstwo i Konserwatorstwo, 44 (2013): 57-73.

WALLIS, Mieczysław. „Wartości estetyczne łagodne i ostre”. W: Wybór pism estetycznych. Red. Teresa Pękala, 197-213. Kraków: Universitas, 2004.

WATSON, John B.: Behaviorism. New York: Norton, 1924.

WeInsteIn, Simcha. „Superman: From Cleveland to Krypton. The Man of Steel's Jewish roots”. My Jewish learning. Dostęp 12.05.2021. https://www.myjewishlearning.com/article/ superman- from-cleveland-to-krypton/.

\section{WIZUALNE SŁOWNIKI EMOCJI PODCZAS PANDEMII COVID-19 W MEDIALNYCH PRZEKAZACH ARTYSTYCZNYCH}

\section{Streszczenie}

Niniejsze studium ma na celu zbadanie, jakie emocje były najczęściej komunikowane poprzez sztukę powstałą podczas pandemii oraz jakie nowe symbole emocji, motywy były stosowane w procesie tworzenia. Wykorzystano dwie techniki badawcze: analizę treści oraz metodę Panof- 
sky'ego. Materiał badawczy składa się ze 100 ilustracji z Internetu, uzyskanych po wpisaniu w wyszukiwarce Google słów kluczowych ,art and coronavirus”. Najczęściej pojawiającą się emocją był strach, następnie złość, potem smutek, a najrzadziej radość. Artyści uliczni odwoływali się do szerokiej gamy tematów: kultury religijnej, mitologicznej, popularnej. Analiza materiału badawczego wykazała, że w przestrzeni społecznej i kulturze pojawiły się nowe symbole reprezentujące pandemię SARSCov-2: cząsteczka koronawirusa (symbol uniwersalny emocjonalnie) oraz biała lub niebieska maseczka chirurgiczna i lateksowa rękawiczka symbolizujące strach.

Słowa kluczowe: emocje; sztuka uliczna; COVID-19; religia; mitologia; kultura popularna

\section{VISUAL DICTIONARIES OF EMOTIONS \\ DURING THE COVID-19 PANDEMIC \\ IN ARTISTIC COMMUNICATION}

S u m m a ry

This study aimed to investigate which emotions were most often communicated through art created during a pandemic and new symbols of emotions, themes used in the creation process. Two research techniques were used in the study: content analysis and Panofsky' Method. The research material consists of 100 illustrations from the Internet obtained after entering the keywords article and coronavirus in Google. The most common emotion was fear, next was anger, third was sadness and the least was joy. Street artists appealed to a wide variety of themes: religious, mythological, popular culture. The analysis of the research material showed that new symbols representing the SARSCov-2 pandemic appeared in the social space and culture: the coronavirus molecule (an emotionally universal symbol) and a white or blue surgical mask and latex glove symbolizing fear.

Keywords: emotions; street art; COVID-19; religion; mythology; popular culture. 